$\begin{array}{lll}\text { KULTURA } & \begin{array}{l}\text { POLSKA A KADEMIA NAUK } \\ \text { KOMITET SOCJOLOGII }\end{array} & \text { ISSN 0023-5172 } \\ \mathbf{i} & \begin{array}{l}\text { INSTYTUT STUDIÓW POLITYCZNYCH } \\ \text { SPOLECLENSTWO }\end{array} & \\ \text { 2009, nr } 3 \quad \text { PRZESTRZENIE PAMIĘCI } & \end{array}$

MARCIN KĘPIŃSKI

Uniwersytet Łódzki

\title{
„CZTEREJ PANCERNI” JAKO SOCREALISTYCZNA BAJKA MAGICZNA
}

\begin{abstract}
„Baśń, podobnie jak mit, nie ma ojczyzny i unosi się w powietrzu jak pajęczyna. [...] Czas zatrzymuje się jak w zamku śpiącej królewny. Mała dziewczynka nagle dojrzewa do zamążpójścia, Penelopa nie starzeje się. "Pewnego razu» to znaczy wiecznie i zawsze. Kopciuszek i Tomcio Paluch żyją dziś jak przed tysiącem lat. Pewnego razu, pewnego dnia: oto początek wszelkich baśni”.

Gerardus van der Leeuw, Fenomenologia religii

„Litearura powinna stać się częścią ogólnej sprawy proletariackiej, "trybem i śrubką" jednego, jednolitego, wielkiego mechanizmu socjaldemokratycznego poruszanego przez całą świadomą awangardę całej klasy robotniczej".

Włodzimierz Ilicz Lenin, Organizacja partyjna a literatura partyjna, w: Lenin o literaturze
\end{abstract}

\section{PANCERNI ZAWSZE WIERNI}

„Czterej pancerni” brawurowo wkroczyli do kultury popularnej i wygląda na to, że na długo $\mathrm{w}$ niej pozostaną. Wspominając dziecięce zabawy $\mathrm{z}$ rówieśnikami, niezatarte wrażenia z pierwszej emisji serialu, a dziś oglądając kolejne wznowienia i nowe wydanie książki, mam wrażenie, że mit stworzony przez Janusza Przymanowskiego przetrwał czas Polski Ludowej. Do kontekstu filmowego świata „pancernych” odwołują się reklamy telefonów komórkowych, napisano książkę o kulisach jego powstania, ilustrowane czasopisma publikują sesje zdjęciowe znanych aktorów przebranych za serialowe postaci, a do ga-

Adres do korespondencji: marcin.1970@wp.pl 
zet dodawane są płyty z filmem. Nie przeszkodzą temu protesty kombatantów drugiej wojny światowej i żądania zdjęcia $z$ anteny serialu zakłamującego historię, obrażającego patriotyczne uczucia Polaków. Wokół „pancernych” toczy się dyskusja, pozostają obecni w świadomości społecznej i pamięci zbiorowej kilku pokoleń telewidzów. Serialowi nieraz zarzucano, że jest wyjątkowo kłamliwą propagandą komunistyczną, fałszującą historię, ale pokolenia Polaków nie przyjmują tego do wiadomości. Do dziś jest to, dla wielu z nich, film o przyjaźni i przygodach, o których kiedyś marzyli.

Apel o zdjęcie serialu Czterej pancerni i pies z anteny telewizji publicznej wystosowało Porozumienie Organizacji Kombatanckich i Niepodległościowych w Krakowie. Nazwano go „wykwitem komunistycznej propagandy” i zażądano odesłania do lamusa. „Jest skandalem, że w największym medium niepodległej RP do znudzenia lansuje się kłamliwą wersję dziejów rodem spod ogona psa Szarika" - napisali kombatanci w liście skierowanym na ręce Prezesa Telewizji Polskiej. Rzecznik telewizji zapewnił, że nie zamierza ona emitować seriali zakłamujących przeszłość historyczną. Dodał także, iż podejmuje próby realizacji filmów pokazujących, $z$ wykorzystaniem najnowszej wiedzy historycznej, skomplikowane losy historii naszego kraju ${ }^{1}$. Jesienią 2006 r. Bronisław Wildstein zdją film $z$ anteny. Starania o prawa do emisji natychmiast podjęły inne, prywatne kanały. Kino Polska i Polsat odniosły sukces, przypominając w 2007 r. kolejne odcinki. Emisja kultowego serialu okazała się starzałem w dziesiątkę, widownia szła w miliony telewidzów. Kolejny prezes TVP, Andrzej Urbański, zapowiedział niedaleki powrót „pancernych” na antenę, a kombatanci znów napisali list protestacyjny ${ }^{2}$. Najwyraźniej trudno wyobrazić sobie bez nich telewizję.

Zróżnicowanie głosów historyków, publicystów i środowisk kombatanckich w dyskursie dotyczącym drugiej wojny światowej wiąże się z różnymi interpretacjami wydarzeń historycznych i toczącym się od kilkunastu lat sporem o historię i zbiorową pamięć Polaków ${ }^{3}$.

Według Barbary Szackiej, polska pamięć i upamiętnianie drugiej wojny światowej w okresie PRL wynikały z potrzeby legitymizacji socjalistycznej władzy, która nastała za sprawą „bratniej pomocy” ZSRR. Ta „urzędowa” pamięć wymagała usunięcia z przeszłości wszystkiego, co mogłoby zaszkodzić obrazowi Związku Sowieckiego jako najlepszego przyjaciela i wyzwoliciela Polaków, jak też tego, co wiązało się z przedwojenną Polską i mogło podważyć uprawomocnienie nowej, ludowej władzy. Milczeniem pomijano walkę Armii Krajowej z Niemcami, a przede wszystkim okrutny los polskiej ludności pod

\footnotetext{
1 O perypetiach serialu w IV RP zob.: Orliński 2006; Szczerba 2006; Szewczyk 2006.

2 www. wirtualnemedia.pl

${ }^{3}$ Spór ideologiczny na temat udziału Ludowego Wojska Polskiego w drugiej wojnie światowej przedstawia „Przegląd” z 15 maja 2005 r. w cyklu Wojna i polityka (m.in. Walenciak 2005; Łagowski 2005); zob. też Iggers 2002; Szacka 2006.
} 
sowiecką okupacją (deportacje, zsyłki do łagrów, masakra jeńców w Katyniu). Programowe „zapominanie” przez władzę tego, co działo się na Kresach po 17 września 1939 r., sprawiało jednak trudność. „Rodziło się bowiem pytanie, skąd w Związku Radzieckim wzięło się tylu Polaków, że można z nich było utworzyć nie tylko armię Andersa, ale i Ludowe Wojsko Polskie. Omijano ją [tę trudność] za pomocą formuły: "losy wojny rzuciły ich do...» (tu wymieniano miejscowość lub rejon Związku Sowieckiego, bądź po prostu Związek Radziecki)" (Szacka 2006, s. 154). Kłopot z racjonalnym wyjaśnieniem przyczyn tego stanu rzeczy starano się przezwyciężyć w literackich i kinowych obrazach wojny.

Moja przygoda z Czterema pancernymi $i$ psem zaczęła się, jak w przypadku większości moich rówieśników, od coniedzielnego, długo oczekiwanego seansu kina Teleranka. Niedzielne poranki stały się najważniejszą częścią tygodnia, a przygody Janka, Gustlika, Grigorija, Olgierda i, oczywiście, Szarika na długo zawładnęły dziecięcą wyobraźnią. Mimo pewnej niechęci do systemu komunistycznego, jaką zacząłem przejawiać wraz z dorastaniem, nigdy nie traktowałem filmu o czterech dzielnych czołgistach i psie jako części jego kłamstwa, propagandowej produkcji. Przyznam, że do dzisiaj darzę „serial wszechczasów” ogromnym sentymentem. Książki Janusza Przymanowskiego, na podstawie której powstał film, jako dziecko nie przeczytałem w całości, choć była zapewne we wszystkich bibliotekach, funkcjonujących przecież w PRL w każdej dzielnicy i szkole. Wystarczyło przejść na drugą stronę ulicy, wejść w bramę i biblioteka była o krok. Jeśli jakiejś książki tam nie było, można było pójść na sąsiednią ulicę, gdzie były następne dwie biblioteki dla dzieci, młodzieży i dorosłych. W szkolnej czytelni wszystkie egzemplarze Czterech pancernych i psa były zawsze wypożyczone. Miłośnicy serialu polowali na „luksusowe” wydanie z 1977 r., w twardej oprawie, mieszczące liczne fotosy z filmu. Po latach zdobyłem właśnie ten egzemplarz, podarował mi go znajomy historyk. Jednak w czasach dzieciństwa nigdzie nie mogłem tego wydania wypożyczyć ani kupić, mimo że w PRL książki dla młodzieży drukowano w ogromnych, jak na dzisiejsze czasy, nakładach sięgających kilkuset tysięcy egzemplarzy. Udało mi się przeczytać komiks i pierwszą część powieści o „pancernych”.

Uwagę młodzieży przyciągał przede wszystkim serial telewizyjny, jednak to powieść Janusza Przymanowskiego stanowiła pierwowzór filmowego świata dzielnych czołgistów. Historia największego filmowego mitu PRL rozpoczęła się od książki, którą Janusz Przymanowski napisał na konkurs Wydawnictwa Ministerstwa Obrony Narodowej w 1962 r. Co ciekawe, praca otrzymała jedynie wyróżnienie, nie przyznano jej żadnej nagrody. Do popularności książki pułkownika Przymanowskiego przyczyniła się wrocławska "Gazeta Robotnicza”, która drukowała powieść w odcinkach. Między lipcem a listopadem $1964 \mathrm{r}$. Czterej pancerni i pies zdobyli wielką popularność wśród młodych czytelników. Krytyka dziennikarska zarzucała autorowi, że napisał „bajkę na motywach wojennych”, przedstawiając okrutną wojnę jako męską przygodę i „szkielet dla 
baśniowej fabuły" 4 . Książkę drukowały w odcinkach również „Gazeta Poznańska”, „Płomyczek”, „Życie Warszawy”, „Panorama”, „Kurier Polski”.

Dzieło Janusza Przymanowskiego osiągnęło nakłady wydawnicze rzędu 700 tysięcy i więcej egzemplarzy dopiero w latach siedemdziesiątych, po emisji serialu telewizyjnego. Czterech pancernych i psa drukowano też za granica, we wszystkich krajach dawnego „obozu socjalistycznego”: ZSRR, Bułgarii, Mołdawii, Rumunii, NRD i na Kubie. W Polsce olbrzymią popularność książka zawdzięcza nie tylko serialowi, ale także Klubowi Pancernych, który funkcjonował w latach 1966-1970 - jako program telewizyjny, ale przede wszystkim jako społeczny ruch młodzieżowy.

Po emisji początkowych odcinków serialu, opartego na pierwszej części książki, Janusz Przymanowski został wręcz zmuszony przez czytelników i widzów do napisania następnej, na podstawie której nakręcono drugą i trzecią serię filmu. Zasypywano go listami z prośbą o dalsze przygody bohaterów, żądania otrzymywali też, za pośrednictwem Klubu Pancernych, twórcy serialu. W końcu łódzki „Głos Robotniczy” ogłosił konkurs na pomysły dalszych losów czterech pancernych, z których Janusz Przymanowski skorzystał, pisząc dalsze części książki.

Kim był autor największego filmowego mitu Polski Ludowej? „Nim narodziła się kościuszkowska dywizja, kilka tysięcy Polaków, których losy rzuciły na teren Związku Radzieckiego, walczyło w szeregach Armii Czerwonej. Wielu zdobyło szlify oficerskie, lub podoficerskie, ordery lub medale, przysparzając starym zwyczajem sławy dalekiej ojczyźnie. [...] Jeśli chodzi o mnie, to trafiłem do Armii Czerwonej późno, w styczniu 1943 r. Próbowałem zgłaszać się wcześniej, ale nie brali warszawiaków, ani krótkowidzów" - tak tłumaczył Przymanowski (1967, s. 7), skąd wziął się w Armii Czerwonej, nie wyjaśniając przy tym przyczyn swego pobytu w ZSRR ani co tam robił przed rokiem $1943^{5}$.

Autor Czterech pancernych $i$ psa urodził się w 1922 r., a zmarł w 1998 r., już po upadku w Polsce systemu realnego socjalizmu, którego kulturę tworzył jako pisarz. Oficer, dziennikarz, poeta, tłumacz literatury radzieckiej. Skończył gimnazjum im. Stefana Żeromskiego w Warszawie. Był uczestnikiem kampanii wrześniowej 1939 r., maturę zdał w 1940 r. w Brześciu nad Bugiem. W latach 1940-1943 był internowany i więziony przez władze sowieckie. Pracował w kamieniołomie bazaltu, fabryce metalurgicznej i kołchozie. W 1943 r. wstąpił ochotniczo do Armii Czerwonej, a w listopadzie tego roku znalazł się w I Kor-

\footnotetext{
4 Szerzej o genezie książki i serialu Czterej pancerni $i$ pies oraz ich społecznym odbiorze zob. Łazarz 2006.

$5 \mathrm{Z}$ racji cenzury prewencyjnej nie można było poruszać tematu 17 września 1939 r. i jego konsekwencji - zsyłki Polaków zamieszkałych na Kresach do łagrów. Jedną z pierwszych prób opowiedzenia, jak to w systemach totalitarnych bywało, dokonywanych w formie ezopowych komunikatów, był Początek drogi. Lenino Alojzego Srogi (1974).
} 
pusie Wojsk Polskich w ZSRR i przeszedł z nim szlak bojowy do Warszawy. Korespondent i zastępca naczelnego redaktora gazety I Armii „Zwyciężymy”.

Po 1945 r. wstąpił do PPR, pracował w redakcjach czasopism o tematyce wojskowej: „Skrzydlatej Polski”, „Żołnierza Polskiego”, „Wojska Ludowego”. Członek warszawskiego Komitetu Wojewódzkiego PZPR. Ukończył Wydział Historii Uniwersytetu Warszawskiego. W latach 1980-1985 był posłem na Sejm PRL. Przyjaciel i frontowy towarzysz Wojciecha Jaruzelskiego, deklarował się jako zwolennik wprowadzenia w Polsce stanu wojennego. Odznaczony Krzyżem Walecznych, Krzyżem Grunwaldu, Złotym Krzyżem Zasługi i Orderem Uśmiechu.

Janusz Przymanowski był autorem wielu książek o tematyce wojennej, przedstawiających udział Polaków w walkach na froncie wschodnim drugiej wojny światowej. Jednak w świadomości dorastających w PRL pozostaje autorem tylko jednej, najważniejszej książki dzieciństwa: Czterech pancernych $i$ psa. Jego Tajemnica wzgórza nr 117 była lekturą klasy czwartej szkoły podstawowej, a pierwszą część Czterech pancernych czytały dzieci w klasie piątej. Dla młodszych czytelników Przymanowski napisał Fortele Jonatana Koota.

Prawdziwe ambicje pisarskie i historyczne pułkownika Przymanowskiego możemy poznać czytając Studzianki - reportaż historyczny z bitwy o przyczółek warecko-magnuszewski z 1944 r. Książka jest pełna map, wojskowych diagramów, zwiera dokładne kalendarium wydarzeń, szczegółowo opracowaną bibliografię, jej zaletą są także archiwalne zdjęcia. Przy pracy nad monografią Przymanowski korzystał z pomocy pracowników Wojskowego Instytutu Historycznego i historyków radzieckich. Jako źródła posłużyły mu dokumenty z archiwum Wojska Polskiego i Armii Czerwonej, pamiętniki uczestników tamtych wydarzeń, wywiady przeprowadzone z polskimi i radzieckimi żołnierzami. Autor podróżował też po Polsce i ZSRR, zbierając materiały w terenie - w Studziankach Pancernych i okolicznych wsiach, rozmawiał z żołnierzami, a nawet $z$ marszałkiem Związku Radzieckiego, obrońcą Stalingradu, wyzwolicielem Poznania - Czujkowem. Towarzyszyła tym wszystkim zabiegom dbałość o szczegóły: „Książka ta jest historycznym reportażem. Nie ma w niej ani jednego zmyślonego nazwiska, ani jednego faktu, który by nie miał potwierdzenia w dokumentach, bądź dwu, co najmniej wiarygodnych i zbieżnych relacjach uczestników wydarzeń. [...] Zbieranie materiału i przygotowania autorskie rozpocząłem w 1954 r. - pisał Przymanowski (1979, s. 641-642). — Pierwsze wydanie ukazało się w $1966 \mathrm{r}$. W czasie tych dwunastu lat wielu ludzi okazało mi wyjątkowo serdeczną pomoc [...] Oficerowie 10 Sudeckiej Dywizji Pancernej, ryzykując własne głowy i utratę cennego sprzętu, nauczyli mnie prowadzić T-34 i strzelać z czołgu mniej więcej celnie. Przewodniczący Prezydium PRN Kozienice [...], kierowniczka szkoły im. Brygady Pancernej [...] i proboszcz polskokatolickiej parafii w Studziankach — uczynili wszystko, by ułatwić mi studia terenu, które w sumie trwały czternaście miesięcy". To na podstawie ustaleń $\mathrm{z}$ tej książki pułkownik-literat stworzył postaci i fabułę Czterech pancernych. 


\section{MAGICZNE ODDZIAŁYWANIE „SERIALU WSZECHCZASÓW”}

Od końca lat sześćdziesiątych Janek Kos był bohaterem „żywym”, towarzyszącym codziennemu życiu Polaków. Dzisiaj, po czterdziestu latach, nadal jest w nim obecny. Zastanawiający wydaje się fakt, iż serial skrojony na miarę PRL-u nadal funkcjonuje w świecie popkultury. Co spowodowało długowieczność „czterech pancernych”?

Serial był długi, ale na kolejne, trwające godzinę odcinki czekało się z napięciem i niecierpliwością. Można było oglądać je po wielekroć, nie nudząc się, a bohaterowie dali się lubić. Należy pamiętać o historycznym kontekście lat sześćdziesiątych, kiedy pamięć wojny była wciąż żywa, o jej wydarzeniach dyskutowano w szkole, rodzinie, gronie przyjaciół, funkcjonowała jednocześnie propaganda „socjalistycznego pacyfizmu”. Bohater - Janek Kos - dla starszych, pamiętających drugą wojnę światową, wpisywał się, lepiej lub gorzej, w ich własną biografię, a dla młodszych stanowił postać godną naśladowania w życiu codziennym. Wykorzystywano też fascynację młodzieży techniką (czołg) i wojskiem (oczywiście ludowym). Po emisji serialu uczelnie wojskowe o profilu technicznym przeżywały oblężenie. Odwoływano się do polskich tradycji militarnych, szacunku, jakim cieszył się mundur (zwłaszcza oficerski), honoru i historii oręża (pancerni - spadkobiercy husarii).

Nie bez znaczenia były wartości, jakie film propagował: przyjaźń, poświęcenie, miłość, praca na rzecz wspólnoty, prawość, sprawiedliwość. Serial zawierał także uniwersalne kulturowo elementy, jak topos walki dobra ze złem, w wyniku której w końcu tryumfuje dobro, a zło przegrywa, choć początkowo przeważa, czy topos wędrówki bohatera, pokonującego przeróżne, groźne przeszkody, zdobywającego wiedzę o świecie, miłość i prawdziwą przyjaźń, dokonującego właściwych wyborów. Tęsknota, jaką dziś odczuwa „pokolenie czterech pancernych", nie jest przecież tęsknotą za systemem komunistycznym, za tym, co było w oczywisty sposób złe. Jest raczej nostalgią, sposobem na ponowne przeżywanie ważnego czasu dzieciństwa. „Przeszłość taka ma często status mityczny, gdyż jest niezmienna, jest wartością, która przechowuje się mimo płynącego jednokierunkowo nurtu życia: to oaza pamięci" (Burszta 1996, s. 100). Nostalgia to nasycony emocjami rodzaj pamięci: „Wyraz «nostalgia» [...] nawiązuje do greckich nostos (= powrót) i alogos (= cierpienie), tworzących łącznie pierwotny sens pojęcia nostalgii jako gorącego pragnienia ujrzenia ojczyzny [...]. Uczucie nostalgii odnosiłoby się zatem do czegoś, co było $\mathrm{i}$ jest $\mathrm{w}$ nas samych, ale czego zewnętrzne atrybuty nie są $\mathrm{w}$ danej chwili dostępne" (Burszta 1996, s. 97) Nostalgia to pamięć utraconej rzeczywistości o cechach orbis interior, a więc uważanego za najważniejszy fragmentu świata. Warunkuje ona tęsknotę za czymś nieobecnym, dalekim i dawnym, za mityczną przeszłością i miejscem: „nostalgia za minionym opiera się na przekonaniu, że teraźniejszość jest w sposób zasadniczy odmienna od przeszłości; z refleksji nad tą pierwszą wyłania się obraz drugiej, zawsze w jakimś stopniu zmityzowany" 
(Burszta 1996, s. 102). Konfrontacja teraźniejszości z przeszłością wypada na korzyść tej ostatniej.

Trudno się dziwić, że serial wywierał tak mocne społeczne oddziaływanie. Był doskonale nakręcony, miał świetny scenariusz, wyraziste postaci bohaterów, znakomitą fabułę. Pracowali przy nim wybitni polscy scenarzyści, reżyserzy, operatorzy, aktorzy ${ }^{6}$. Aktorstwo Janusza Gajosa było tak przekonujące, że postać Janka Kosa niemal zamknęła mu drogę do dalszej kariery. Serial odwoływał się do rozbudowanej wyobraźni dzieci i młodzieży, która w spontaniczny sposób zareagowała na stworzony przez Przymanowskiego Klub Pancernych, będący kontynuacją serialowego świata.

Do skonstruowania postaci czołgistów i ich przygód autor wykorzystał biografie żołnierzy Brygady Pancernej im. Bohaterów Westerplatte. Wzorem dla filmowego Olgierda Jarosza był radziecki kapitan Wiktor Tiufiakow, Gustlika Ślązak Ernest Jeleń, Janka Kosa - równie młody Stanisław Rzeszutek, a Gruzina Saakaszwilego - Wano Keczakmadze, dowódca Przymanowskiego z Armii Czerwonej ${ }^{7}$.

„Janek trafiający w cel, Gustlik, o mięśniach ze stali, Grześ kierowca wyborny i Wasyl różnooki, czytający przyszłość z chmur, śmiała Marusia - Ogoniok, zalotna Lidka... Czy żyli naprawdę? Czy takie właśnie mieli przygody? [...] Przygód nie zmyśliłem, bo i po co, skoro wystarczy porozmawiać z frontowymi kolegami, by dowiedzieć się prawdziwych i znacznie ciekawszych, niż te $z$ fantazji wysnute. [...] Chcę, by w waszej pamięci zostali zawsze młodzi, odważni i wierni, byście wzięli ich jako towarzyszy na szlak wielkiej i trudnej przygody waszego życia" — odpowiadał Janusz Przymanowski (notka na okładce wydania z 1968 r.) na najczęściej padające na spotkaniach autorskich pytanie: „Czy pancerni istnieli naprawdę?”.

Czterej pancerni $i$ pies nie są wymysłem propagandy, zakłamującym historię. Są przykładem na mityzację przeszłości historycznej, dokonującą się w pamięci zbiorowej. Polega ona na „spontanicznym przekształcaniu postaci oraz wydarzeń przeszłości w bezczasowe wzory i personifikacje wartości, które sankcjonują zachowania i postawy ważne dla życia zbiorowości" (Szacka 2006, s. 24). W serialowym micie nie ma miejsca na racjonalność, związany jest on z uczuciami, przemawia nie do rozumu, ale do serca. Czas, do którego odwołuje się serial — wojna, jest czasem sakralnym, diametralnie różnym od rzeczywistości dnia codziennego.

Podobieństwa między „pancernymi” a mitem na tym się nie kończą. „Mit jest silnie obciążony wartościowaniem. Świat mitu to świat istot krańcowo złych albo krańcowo dobrych i nie ma w nim miejsca na rzeczy neutralne.

${ }^{6}$ Twórcy serialu to między innymi: Henryk Kluba, Konrad Nałęcki, Agnieszka Osiecka, Wojciech Kilar, Roman Kolski i plejada wybitnych aktorów, obsadzanych nawet w rolach drugoplanowych.

7 Więcej na temat pierwowzorów postaci wykorzystanych przez Przymanowskiego zob: Łazarz 2006. 
Wszystkie są bądź przyjazne, bądź wrogie” (Szacka 2006, s. 75). Bohaterowie serialu stali się $\mathrm{W}$ pamięci zbiorowej postaciami mitycznymi — „wzorami postaw i zachowań, precedensami ważnymi dla istnienia i sprawnego funkcjonowania grupy oraz symbolami doniosłych dla niej wartości" (Szacka 2006, s. 93-94).

Są jeszcze inne kulturowo ważne aspekty niezwykłej popularności serialu i powieści Czterej pancerni i pies. Będące niegdyś w żywym obiegu, kiczowate artefakty z nimi związane dziś stanowią rzadki kolekcjonerski rarytas. Inny dowód niezwykłej popularności serialu telewizyjnego to spotkania i festyny $z$ „żywymi pancernymi”, czyli aktorami odtwarzającymi role bohaterów filmu. Dzięki nim „pancerni” bardziej zbliżyli się do realnego życia, pełniąc w ubogiej treściowo socjalistycznej kulturze popularnej rolę podobną do tej, jaką w kulturze typu ludowego pełniły kalwarie czy odtwarzane w teatrze ludowym misteria Męki Pańskiej. Idoli można było zobaczyć na własne oczy i dotknąć, a tym samym zaspokoić potrzebę sensualizmu przeżycia „mistycznego”, kontaktu z zaproponowanym przez władzę spauperyzowanym sacrum. Oczywiście, dominujący był tu element rozrywki, ludyczna funkcja kultury. Spotkania takie organizowano od 1967 do 1969 r., gromadząc olbrzymią publiczność na stadionach i innych masowych obiektach sportowych. Dramatyczny przebieg miał łódzki spektakl, zaplanowany w Hali Sportowej, a mający się zacząć na Placu Wolności. Szczelnie wypełniający ulicę Piotrkowską i Śródmieście tłum o mało nie zadeptał herosów. Milicja nie była w stanie opanować sytuacji, aktorów ukryto więc i oddzielnie odwieziono na miejsce spotkania wozami straży pożarnej (Łazarz 2006).

Ze względu na tego rodzaju wydarzenia i całkowite utożsamienie odtwórców ról filmowych z granymi przez nich postaciami aktorzy odmówili dalszego udziału w tournée po Polsce: „Bałem się, że przestaję być aktorem i staję się bohaterem II wojny światowej — mówi dziś Włodzimierz Press. - Widzowie zapomnieli o tym, że jesteśmy tylko odtwórcami" (Łazarz 2006, s. 218). Świat wykreowany przez serial wykraczał daleko poza ekran telewizora. Na przełomie lat sześćdziesiątych i siedemdziesiątych istniał fenomen Telewizyjnego Klubu Czterech Pancernych. Widowisko, a zarazem młodzieżowy ruch społeczny, stało się wyjątkową zabawą o wymiarze edukacyjnym i dydaktycznym, zainspirowaną na ogromną skalę przez telewizję. Podczas wielu akcji młodzi klubowicze poznawali historię Polski, dbali o zwierzęta, pomagali starszym i potrzebującym, a w maju 1970 r. na wezwanie Klubu milion dzieci zdawało egzamin na kartę rowerową.

\section{„CZTEREJ PANCERNI” — BAJKA MAGICZNA I EPIKA BOHATERSKA}

Władimir Propp zaproponował wydzielenie z szerokiego, różnorodnego tematycznie obszaru bajek modelu bajki magicznej, charakteryzującej się szczególnym zestawem cech. „Wychodzę z założenia - pisał (Propp 2003, s. 9) - 
iż istnieją jakieś szczególne bajki, które można określić mianem «magicznych». [...] Badaniu będzie podlegać taki gatunek tych bajek, które rozpoczynają się od poniesienia jakiejś straty i szkody (porwanie, wygnanie itp.) albo od pragnienia posiadania czegoś (car posyła syna po ognistego ptaka) i rozwijają się poprzez wyprawę bohatera $z$ domu, spotkania $z$ ofiarodawcą, który ofiaruje mu magiczny środek albo pomocnika, przy pomocy którego przedmiot poszukiwań zostaje odnaleziony. Dalej w bajce mamy pojedynek z przeciwnikiem [...], powrót i pościg. Często kompozycja ta zostaje dodatkowo skomplikowana". Bajka magiczna jest całością o powiązanych ze sobą fabułach, którymi rządzą funkcje/działania - niezmienne stałe.

Atrybuty bohaterów funkcjonujących w bajce magicznej mogą się zmieniać, ale nie zmieniają się podejmowane przez nich działania. Wyodrębnienie stałych elementów bajki pozwala badać ją i porównywać w kontekście mitów, literatury, religii społeczności i kultur. Nie chcę w tym miejscu szczegółowo opisywać funkcji magicznych postaci działających w bajce, których Propp (1976, s. 58-59) wymienia ponad trzydzieści i które wyznaczają rozwój akcji bajkowej opowieści. Funkcje są stałymi elementami bajki, ich liczba jest ograniczona, następstwo jednakowe (kradzież nie może nastąpić przed wyłamaniem drzwi).

Nie twierdzę, że Janusz Przymanowski specjalizował się w pisaniu bajek magicznych rodem $z$ terenów dawnego ZSRR, choć z pewnością znał folklor rosyjski i fascynował się kulturą naszych „słowiańskich braci”. Chcę jedynie podkreślić, że fabuła książki Czterej pancerni i pies zawiera wiele elementów charakterystycznych nie tylko dla konstrukcji ludowej epiki bohaterskiej, ale i dla opracowanego przez Władimira Proppa modelu bajek magicznych. Być może właśnie dlatego powieść i serial cieszyły się i nadal cieszą tak dużą popularnością, a ich bohaterowie wpisali się w zbiorową pamięć polskiego społeczeństwa jako część kontekstu kulturowego, do którego współcześnie możemy się odwoływać.

Spróbujmy przyjrzeć się Czterem pancernym i psu z perspektywy cech bajki magicznej.

\section{Oddalenie, nieszczęście i przeciwdziałanie}

Bajka magiczna zaczyna się od słów: „W pewnym królestwie, w pewnym państwie” — w wyniku których „słuchacz wprowadzony zostaje w szczególny nastrój, w nastrój epickiego spokoju. Ale nastrój ów okazuje się zwodniczy. Przed słuchaczem szybko odsłonią się wydarzenia o wielkim napięciu i wielkiej sile namiętności" (Propp 2003, s. 31).

Ważnym elementem bajkowego świata jest rodzina, która na początku żyje spokojnie, szczęśliwie i nic nie zakłóca jej szczęścia. Jednak nagle pojawią się szczególne okoliczności, zwiastujące nieszczęście: „Kupiec jedzie handlować, książę udaje się na polowanie, król — na wojnę itd.; dzieci albo żona, czasami brzemienna, pozostają same, bez obrony. W ten sposób przygotowany 
zostaje grunt pod nieszczęście. Skrajną formą oddalenia jest śmierć rodziców. Od śmierci albo oddalenia rodziców rozpoczyna się bardzo wiele bajek" (Propp 2003, s. 31-32).

W szczęśliwym życiu rodziny Janka Kosa nagle pojawiają się dramatyczne okoliczności, zmieniające zwyczajny, uporządkowany bieg zdarzeń. Wtargnięcie chaosu w dziecięcy świat poprzedza wyjazd Ojca, nauczyciela i oficera rezerwy, na wojskową placówkę Westerplatte: „Jakieś nieszczęście stanowi podstawową fabułę zawiązania akcji. $Z$ nieszczęścia i przeciwdziałania rodzi się fabuła. [...] Zazwyczaj na końcu bajki nieszczęście zmienia się w szczęście" (Propp 2003, s. 42-43). Nasz bohater przeżywa dramatyczne przygody, zdobywa wiedzę o świecie i sobie samym, pokonuje zło, a wreszcie wszystko dobrze się kończy.

Kiedy poznajemy Janka Kosa, wędruje po syberyjskiej tajdze w poszukiwaniu zwierzyny, jest towarzyszem i uczniem starego myśliwego. Nie od razu dowiadujemy się o tragicznej przeszłości chłopca. Wypadek podczas polowania, w którym ginie suka Mura, matka Szarika, podsuwa wspomnienie o innym nieszczęściu: „I nagle, jak dalekie echo wystrzału, jak krzyk ptaka spoza chmury, przyszło wspomnienie gruzów domu, zapachu spalenizny i pokruszonego na miał tynku. - Sam zostałeś, Szarik. [...] Tak może się trafić i psu, i człowiekowi — pomyślał Janek. On też został prawie sam. By nie być samotnym zawędrował pół świata. Nie znalazł tego, kogo szukał" (Przymanowski 1977, s. 9). Motyw wędrówki jest wpisany w dzieje Janka Kosa, który jest typowym bohaterem sierotą.

Matkę zabili Niemcy, a on, ukrywając się przez wrogiem, wydostał się z Gdańska i wyruszył na poszukiwania ojca. Poszukiwania się nie powiodły, a bohater dotarł bardzo daleko, nad Ocean Spokojny, na kraj św i a ta: „Głodny i bosy trafił na Starego, to znaczy na myśliwego, którego nazywano Jefim Semionycz. Tam już został, bo dalej nie było gdzie szukać" (Przymanowski 1977, s. 39). Zauważmy, że Janek Kos jest postacią nadrzędną w Czterech pancernych, wokół niego osnuta jest akcja, to on stanowi centralne odniesienie dla wszystkich wątków: „Zawsze w centrum uwagi znajduje się Janek, a obraz jego czynów dopełniają czyny załogi «Rudego». Taki sposób narracji — cyklizacji zdarzeń i wątków wokół jednej postaci - przypomina konstrukcję tradycyjnego eposu rycerskiego" (Sulima 1985, s. 311). Przypomnijmy przykłady Parsifala, Tristana i Rolanda. Bohater-sierota jest „główną postacią mitu, bajki bohaterskiej i tradycyjnego eposu" (Sulima 1985, s. 311).

Zanim Janek podejmie na nowo pełną nadzwyczajnych przygód wyprawę, musi dokonać bohaterskiego czynu. Nie szuka narzeczonej, bo to „wyprawa syna w poszukiwaniu ojca, wiążąca się z motywem zemsty rodowej" (Sulima 1985, s. 312). Chłopiec nienawidzi wrogów, sprawców cierpień jego rodziny, kraju i wszystkich dobrych ludzi. Ma do tego prawo. Nie jest to jednak zacięta, zimna nienawiść. Janek jest szlachetny, podobnie jak jego towarzysze walki, potrafi okazać wielkoduszność, a nawet litość. To postawa zasługująca 
na uznanie, tym bardziej że wróg nie posiada podobnej cnoty. Już jako dowódca czołgu Kos przygarnia zabłąkane niemieckie dziecko, ratując je przed głodową śmiercią. Początkowo załoga sądzi, że mały jest Polakiem, przynoszą mu chleb i mleko, bawią się z nim. Wypowiedziane w obcym, wrogim języku słowa momentalnie zmieniają sytuację, przywołując nieludzki, obcy świat i metonimię śmierci: „Gib mir! Oh, gib mir diesen Frosch! Po tych słowach roześmiane wokół twarze zastygły. [...] Wrócił Tomasz z grubą kromką chleba w jednej i menażką pełną mleka w drugiej. Stanął zdziwiony bezruchem i nagłą ciszą. [...] - Milch. Brot. - Szkop? - Spytał Tomasz. - Szwabski syn - wycedził przez zęby Wichura. Znowu milczeli długą chwilę. [...] Wreszcie Janek głęboko westchnąwszy, wyrzucił z siebie jedno słowo: - Dziecko. [...] Wziął z rąk Czereśniaka chleb i podał chłopcu" (Przymanowski 1977, s. 301).

\section{Kręte ścieżki wędrówki bohatera}

„Kompozycja bajki zasadza się na przestrzennym przemieszczaniu się bohatera [...] charakterystyczna jest nie tylko dla bajki magicznej, ale i dla eposu (Odyseja) i powieści [...] Na tej drodze mogą spotkać bohatera najrozmaitsze przygody" (Propp 2003, s. 44). Przygody w bajkach są podobne, powiada Propp, podlegają ścisłym prawidłowościom. Kolejne ważne spostrzeżenie dotyczy bajkowej przestrzeni i przemieszczania się w niej bohatera. „Droga istnieje wyłącznie w opisie kompozycyjnym, nie pojawia się jednak jej faktyczny opis. Drugi etap drogi prowadzi od leśnej chatki do innego królestwa. Dzieli je ogromna przestrzeń, lecz pokonuje się ją momentalnie" (Propp 2003, s. 44-45).

Pierwszy etap wędrówki Janka - droga z Polski nad Ocean Spokojny nie jest w Czterech pancernych dokładnie opisany. Bohatera spotykamy na Syberii. Drogę powrotną, przystanki od obozu szkoleniowego nad Oką i do Polski, Janek pokonuje błyskawicznie. Kolejne etapy jego podróży na Zachód to: Lublin, Warszawa (a właściwie Praga), Pomorze, Niemcy i Berlin. Po drodze spotyka drużynę (załogę) walczy, zakochuje się, zostaje ranny, wymyka się wrogom i pokonuje ich dzięki magicznemu pomocnikowi, sprytowi, nabytym umiejętnościom. „Przestrzeń w bajce odgrywa podwójną rolę. $Z$ jednej strony istnieje ona $\mathrm{w}$ bajce, stanowi absolutnie niezbędny element fabuły. $Z$ drugiej strony jest tak, jak gdyby w ogóle nie istniała. Bieg akcji wyznaczają szczegółowo opracowane postoje" (Propp 2003, s. 45).

Propp powiada, że przestrzeń i droga w konstrukcjach literackich, jak Odyseja, zostały opracowane inaczej, w sposób epicki. Wysnuwa stąd wniosek, że przestrzeń stanowi swoistą nadbudowę w stosunku do elementów obrzędowych, istniejących w fabule bajki pod postacią postojów. „Przestrzeń wdarła się $\mathrm{w}$ coś, co istniało już wcześniej. Podstawowe elementy istniały przed pojawieniem się wyobrażeń przestrzennych. [...] Wszystkie elementy postojów istniały już wcześniej pod postacią obrzędu" (Propp 2003, s. 45). Ten obrzęd to rytuały inicjacyjne, rites de passage, powiada Propp. „Bajka zachowała nie 
tylko ślady wyobrażeń o śmierci, ale i ślady bardzo rozpowszechnionego niegdyś obrzędu [...] — Obrzędu wtajemniczenia młodzieży osiągającej dojrzałość [...]" (Propp 2003, s. 51). W czasie tego obrzędu młodzieniec umierał, pożerany przez inicjacyjnego potwora, a rodził się mężczyzna. Janek-chłopiec musi stać się mężczyzną, poznać zwyczaje myśliwskie, wiedzę historyczną, życiowe prawa i wymogi, sposoby walki z wrogiem. Rolę potwora możemy tu przypisać wszechogarniającej, niszczącej życie i porządek ludzkiego świata wojnie, zabijającej w bohaterze dziecko.

\section{Las, nauczyciel i magiczny pomocnik}

"Idąc, "gdzie oczy poniosą", bohater, albo bohaterka trafia do ciemnego, gęstego lasu" (Propp 2003, s. 54). Las to rekwizyt obrzędów przejścia, metonimia śmierci, odwróconego porządku orbis exterior. „Las w bajce odgrywa rolę powstrzymującej przeszkody. Las, do którego trafia bohater, jest nieprzenikniony" (Propp 2003, s. 54). Zanim znów rozpocznie swą epicką przygodę, musi spełnić warunek bohaterskiego czynu. Przygotowuje go do tego Stary, a nauka trwa trzy lata: „Mieszkał już w nowym domu trzecie lato. Nauczył się wielu rzeczy: chodzić po tropie jak wilk, czytać wiatr, rozróżniać zapachy lasu i zwierząt, rozumieć szelesty i ślady, poruszać się cicho, sprawnie i szybko. Nauczył się tak strzelać, by z małokalibrówki trafiać w oko wiewiórki, nie psując wybielonego zimą futra. Trzecie lato wędrował po leśnych ścieżkach. Do dziś nie zastanawiał się, dokąd te ścieżki prowadzą" (Przymanowski 1977, s. 9).

Syberyjska puszcza uwięziła zatem Janka na trzy lata, w tym czasie pobiera od przewodnika-starca istotne nauki. Jednak i tam docierają echa wojny, która w końcu się o bohatera upomina i musi on wyruszyć w dalszą drogę. Wcześniej jednak zostaje odpowiednio przygotowany i otrzymuje dary.

Dalszą kompozycję bajki wyznacza otrzymanie magicznego środka - mówi Propp. W tym celu wprowadza się nową postać, którą jest ofiarodawca. „Klasyczną formą ofiarodawcy jest Baba Jaga” (Propp 2003, s. 49). Zamiast niej w bajce może tę rolę pełnić starzec. „Nauczyciel, do którego trafia chłopiec, jest starcem, czarownikiem, lichem leśnym, mędrcem. Żyje za morzem. [...] Nauczyciel przychodzi z lasu, żyje w innym królestwie [...]" (Propp 2003, s. 106). W Czterech pancernych taką postacią jest Jefim Semionycz — nauczyciel surowy i wymagający, mądry i sprawiedliwy Starzec. Przygarnia on bohatera do swego domu, przekazuje wiedzę o życiu w lesie, zwierzętach, tajnikach przyrody, zasadach walki, polowania, przetrwania ${ }^{8}$. Starzec ofiarowuje Jankowi ubranie myśliwego, bagnet - pamiątkę po polskich zesłańcach oraz cudowne zwierzę - pomocnika.

\footnotetext{
8 Pomijam tu topos inicjacji, ryty graniczne, strukturalny model medialności i separacji, pobytu w „nienormalnym” czasie i przestrzeni (Leach, Greimas 1989).
} 
Zarówno serial, jak i książka Janusza Przymanowskiego poruszają motyw przyjaźni człowieka i zwierzęcia. „Jedność człowieka i zwierzęcia zastąpiona zostaje przyjaźnią między nimi, przy czym owa przyjaźń oparta jest na pewnych umownych prawach" (Propp 2003, s. 166). Relacja przyjaźni wyraża się we wzajemnej pomocy, zwierzę ostrzega człowieka przed niebezpieczeństwem, ocala przed wrogami, wskazuje zagubioną drogę. Bohater otrzymuje magiczne zwierzę w lesie, magiczny pomocnik towarzyszący bohaterowi „stanowi wyraz jego siły i zdolności" (Propp 2003, s. 179). Może należeć do kategorii zwierząt (orzeł, koń, wilk) bądź przedmiotów (latający dywan, różdżka), które przenoszą bohatera do następnego etapu wędrówki, do drugiego królestwa bądź innej krainy, wypełniając dlań różne zadania. Możemy się zastanowić, ile z cech pomocnika ma czołg, nazwany przez pancernych „Rudy”. Niewątpliwie rolę magicznych narzędzi w przygodach Janka pełni broń, której z mistrzostwem i doskonale używa - zdobyczny karabin snajperski i pistolet. Oba narzędzia są darami od przyjaciół, z którymi Janek zawarł pobratymstwo przez wspólny udział w walce.

Opis nauk młodego bohatera pozwala nam dostrzec wspólne motywy bajki ludowej i powieści Janusza Przymanowskiego. Jefim Semionycz, czyli starzec-opiekun zastępujący Jankowi ojca, udziela mu lekcji przetrwania w groźnym świecie, przygotowując go do wyprawy na wojnę: „Charakterystyczne zbieżności z ludową tradycją epicką da się odczytać w wyraźnie na kartkach Czterech pancernych określonej funkcji «starca-opiekuna». [...] Z postacią "starca-opiekuna» wiąże się zazwyczaj typowy motyw epicki opiewający pierwszy wyczyn młodego, zazwyczaj dziecięcego bohatera" (Sulima 1985, s. 312). Janek Kos w wieku szesnastu lat zabija ussuryjskiego tygrysa, ratując przy tym od śmierci swego opiekuna. Zostaje nagrodzony pierwszym trofeum - uszami tygrysa, otrzymuje też w darze „czarodziejskiego pomocnika” — psa Szarika. Trofeum przyda się nieraz jako dowód dla niedowierzających bohaterowi ludzi, a roli psa nie da się przecenić. Szarik będzie wiernym druhem chłopca, wielokrotnie uratuje swego pana i całą załogę czołgu od śmierci z rąk wroga. To on jako szczeniak wyczuł zbliżającego się tygrysa i ostrzegł przed nim myśliwych. Pomógł Jankowi dostać się do pancernej kompanii, to dzięki niemu załoga „Rudego" wydostała się z okrążenia, radziecki saper rozminował fort, Janek zabił niemieckiego snajpera, a Tomek Czereśniak nie został zastrzelony przez swoich jako szpieg. Nie sposób wyliczyć wszystkich zasług „cudownego pomocnika”. Serialowa załoga, dowódca brygady i żołnierze radzieccy porozumiewają się z psem jak z człowiekiem. W bajce epickiej magiczny pomocnik — koń, orzeł, wilk, pies - towarzyszy bohaterowi w wyprawie, wybawiając go z przeróżnych opresji: „W Czterech pancernych funkcję czarodziejskiego pomocnika spełnia pies Szarik. Pokrewieństwo $z$ tradycyjnym schematem narracyjnym wydaje się tym bliższe, że w grę wchodzi znów motyw «sieroctwa». Ginie przecież rozszarpana przez tygrysa suka Mura, a los przypisany Jankowi jest już tym samym epickim losem jego czarodziejskiego pomocnika" (Sulima 1985, s. 313). 


\section{ZBRATANIE}

Motywem epiki bohaterskiej $w$ Czterech pancernych jest zbratanie w pojedynku między Grzegorzem a Jankiem: „Pobratymstwo przez pojedynek łączy na przykład Oliwiera z Rolandem, Kostię Nowotarżanina z Wasylim Busłajewiczem. Pojedynek był warunkiem przyjęcia do Rycerstwa Okrągłego Stołu, był także potwierdzeniem braterstwa" (Sulima 1985, s. 314). Tego rodzaju więź pomiędzy mężczyznami jest charakterystyczna nie tylko dla ludowej wyobraźni i literatury. Wojna to czas zawierania przyjaźni na śmierć i życie, budowania opartych na altruizmie zespolów młodych mężczyzn, poddanych jednakowym próbom i narażonych na te same niebezpieczeństwa.

Innym motywem jest drużyna towarzysząca bohaterowi we dnie i w nocy, pomagająca w niezwykłych czynach, składająca się z dzielnych rycerzy: „Wśród typowych i powtarzających się jednostek narracyjnych spotykamy obraz drużyny nierozerwalnie związany z ogólną koncepcją epickiego losu bohatera" (Sulima 1985, s. 316). Do pancernej drużyny należą: Olgierd, meteorolog wróżący z chmur, siłacz Gustlik, wreszcie pełen zapału Grigorij, doskonały kierowca i mechanik czołgu. Dołącza do nich Janek, przyjęty po dokonaniu niezwykłego czynu — trafia trzy razy pod rząd w środek tarczy: „Doskonale w popisie rycerskich talentów wypada główny bohater Czterech pancernych — Janek Kos. [...] Trzy dziesiątki uzyskane na strzelnicy awansują młodego bohatera (i jego psa) w poczet «rycerskiego stanu» pancerniaków" (Sulima 1985, s. 319).

Tworzą oni załogę spojoną więzią braterstwa walki, silniejszą niż więź rodzinna. W dowódcy czołgu możemy odnaleźć związki z postacią wróżbity, decydującego o rozpoczęciu wyprawy. Gustlik jest najbardziej typową dla epiki bohaterskiej postacią ludowego siłacza. Grigorij Saakaszwili to nie tylko kierowca czołgu, ale i świetny jeździec, doskonale władający szablą. Rycerską broń przekazuje mu umierający polski ułan, a gruziński dżigit udowadnia, że jest odpowiednim kandydatem. Szabla towarzyszy mu w momentach klęski, śmiertelnie groźnych. „Pancerni” zostają złapani przez Niemców. Załoga, zamknięta $\mathrm{w}$ ogołoconym $\mathrm{z}$ amunicji czołgu, zostaje zmuszona do jazdy na wprost dział przeciwpancernych. Grześ odczuwa strach: „Po twarzy mechanika wpatrzonego w lufę pistoletu maszynowego spływały grube krople potu. Drgnęły mięśnie zaciśniętych szczęk. [...] Sięgnął w lewo do kontaktu i przypadkiem dotknął jelca szabli. Usłyszał cichy przyśpiew. Cofnął rękę. Melodia zgasła. Wyciągnął ramię $z$ powrotem, zacisnął palce na rękojeści. Z oddali nadbiegły znajome tony pieśni, osłabły, wróciły mocniej. [...] To mógł być zarówno Amiran Daresdżamidze skrzykujący pancerną drużynę, jak Grigorij Saakadze zwołujący powstańców przeciw safawidzkim najeźdźcom. [...] i nagle Saakaszwili zrozumiał, że to dedamitca - matka ziemia powtarza kroki idących do boju Gruzinów. Zrozumiał, wziął powietrze głęboko w piersi i niespodzianie dla siebie, dla załogi, dla strzegącego Niemca zaśpiewał pełnym czystym głosem: - Kartwelo theli hmals ikar..." (Przymanowski 1977, s. 399). Grigorij, podobnie jak 
Janek, Gustlik i Tomasz, czuje łączność z ziemią, jest dzieckiem natury, dobrze znającym jej tajemnice. Niemcy przeciwnie - niepewnie czują się w lesie, boją się ciemności, nie znają języka leśnych stworzeń. Zatracając swoje człowieczeństwo i uczucia, stali się podobni maszynom, swoim ulubionym wojennym zabawkom, niosącym śmierć.

Porucznik Olgierd Jarosz przejmuje od Starca - Jefima Semionycza rolę opiekuna głównego bohatera. Dowódca „pancernej drużyny” uczy Janka żołnierskiego rzemiosła, zna odpowiedź na każde pytanie, opowiada chłopcu o swej wojennej drodze, naznaczonej cierpieniem, walką i męstwem. Zarazem opiekuje się nim i czuwa, by nie stała mu się krzywda. Jest dla Janka wzorem do naśladowania i starszym bratem. Gdy ginie śmiercią bohatera, ratując czołg przed ogniem, Kos przejmuje po nim dowództwo i robi wszystko, by godnie go zastąpić. Zdjęcia i odznaczenia Olgierda, niczym nośniki pamięci, zdobią wnętrze czołgu, przypominając o bohaterskiej przeszłości i powodach, dla których toczy się wojna. Sam dowódca jest duchem opiekuńczym załogi, a Janek w trudnych chwilach patrzy na jego zdjęcie, dotyka Krzyża Virtuti Militari i zastanawia się, jak powinien postąpić. Przedmioty, pozostawione przez Olgierda stają się, podobnie jak tygrysie uszy, amuletami Janka Kosa.

Nosi je przy sobie, chroniąc przed zniszczeniem bądź zagubieniem, wierzy, że przynoszą powodzenie i żołnierskie szczęście. „Amuletami mogły się stać pierścień, kamień, książka, podkowa, część zwierzęcia. Działo się tak zwłaszcza gdy przedmiot taki trafiał do człowieka przypadkowo, został znaleziony w szczególnych okolicznościach i miejscu, bądź został podarowany, a więc «przybył» ze sfery obcości [...] funkcje amuletu, chroniącego i przynoszącego szczęście, spełniają więc przede wszystkim przedmioty, o których zakłada się, że mają związek z sacrum, z obszarem zaświatowym" (Kowalski 1989, s. 20$-21)$.

\section{Ognisty smok - niszcząca wojna}

Dla czterech pancernych wojna jest siłą niszczącą ich dotychczasowe uporządkowane życie. Grigorija odrywa od rodzinnych, górzystych stron, do których nieustannie tęskni. Gustlikowi zabiera nie tylko spokojne życie u boku rodziców, ale i tożsamość. Zostaje uznany za Niemca i wcielony do Wehrmachtu, skąd dezerteruje. Olgierdowi wojna zabiera ojca i ukochany zawód meteorologa. Najbardziej pokrzywdzony jest Janek, który traci nie tylko szczęśliwe dzieciństwo, ale także dom i oboje rodziców. Wojna jest przedstawiona jako śmiertelne zmagania, w których nie ma miejsca na honorowe reguły gry, a od przeciwnika nie można oczekiwać litości. Załoga — drużyna, nowa rodzina Janka - w każdej chwili może zostać unicestwiona, żywcem spalić się w czołgu („czołgowa śmierć”). Wojna, niczym potwór z bajki, niszczy wszystko na swojej drodze. Rolę wojny w powieści Janusza Przymanowskiego możemy porównać do roli Smoka w bajce magicznej. „Smok jest istotą ognistą. [...] Związek 
smoka z ogniem stanowi jego stałą cechę" (Propp 2003, s. 238). Smok chce spalić swoim płomieniem bohatera, grozi unicestwieniem jego królestwa (spaleniem krainy na popiół). W Czterech pancernych wojna ma swoich ulubieńców Niemców, którzy grożą ludzkości unicestwieniem, rozpalają wojenną pożogę.

Czy możemy próbować tłumaczyć taką a nie inną kompozycję powieści Janusza Przymanowskiego uniwersalnością struktury bajki magicznej? Czy raczej potrzebą tworzenia socjalistycznego folkloru? Folklor wszak „pojmowany tu jako sztuka pierwotnie synkretyczna (różnicująca się w procesie historycznego rozwoju) może być porównywany $z$ dramatem, opera, filmem czy widowiskiem telewizyjnym - jako przejawami sztuk wtórnie synkretycznych" (Sulima 1985, s. 7). Być może odpowiedzią są słowa Władimir Proppa (2003, s. 401): „Nowa społeczna funkcja fabuły, jej czysto artystyczne wykorzystanie, wiąże się z zanikiem ustroju, który go stworzył”. Parafrazując jego myśl, moglibyśmy stwierdzić, że również realny socjalizm tworzył swoje własne bajki, pozostające jednak w kręgu pewnych uniwersalnych struktur kulturowych i zachowujące typowości ludzkich losów. Echa folklorystycznego słowa, historycznie zmiennego, funkcjonującego w różnych obiegach, możemy odnaleźć w kulturze popularnej, gdzie swoje miejsce znajduje odwieczny motyw walki dobra za złem. Ludzka świadomość, starając się porządkować i opisywać świat, czyniła to $\mathrm{w}$ podobny, uniwersalny sposób, niezależnie od odmienności kulturowej i czasoprzestrzennych różnic. Te interpretacje i opis możemy odnaleźć w fabułach i przejawiających się w nich motywach obrzędów i mitów. „Literatura bowiem, w jego [Władimira Proppa - M.K.] przekonaniu, właśnie w nich jest zakorzeniona, nie da się jej zrozumieć, ani opisać, bez konfrontacji z folklorem słownym, i, ostatecznie, pozasłownym" (Ulicka 2000, s. 9).

Źródła wielkich toposów literackich mają korzenie archaiczne, są często wspólne, powszechne, powtarzalne - twierdzi Propp. Zarówno bajka, jak i literatura są systemami przekazu językowego, rządzącymi się swymi wewnętrznymi prawami. Bajka, starsza od literatury, stanowi swoiste archiwum pamięci zbiorowej. Czymże jest bajka, jeśli nie „swoistym zapisem mądrości, przekazywanym z pokolenia na pokolenie i utrwalającym wartości elementarne"? (Ulicka 2000, s. 19). Ten zapis dotyczy niekiedy pewnej grupy etnicznej, ale też może wędrować od narodu do narodu, przekraczając granice i kultury, wzbogacając poetyckie bogactwo człowieka. Literatura, mówiąc słowami Eliadego, jest córką mitologii.

Toposy obecne $\mathrm{w}$ przygodach pancernych, znajdziemy $\mathrm{w}$ mitologii, ludowej epice bohaterskiej wszystkich kręgów kulturowych na przestrzeni wieków, w eposach rycerskich czy nawet powieści historycznej: „Olbrzymia popularność bohaterów Czterech pancernych potwierdza fakt, że ich książkowe i filmowe losy są przedłużeniem tych marzeń o bohaterstwie, prawdzie i wzniosłości, 
jakie realizowały się $\mathrm{w}$ ludowym eposie, $\mathrm{w}$ pieśni historycznej, micie i bohaterskiej bajce" (Sulima 1985, s. 310). Oczywiście, literatura i folklor inaczej przedstawiają i widzą świat: „literatura dopuszcza zmienność światów, kultur, osobowości, gdy folklor raczej "przyrównuje» i ujednolica [...] Literatura przekracza świat, folklor go reprodukuje, przystosowując się do jego przemian. [...] Literatura stara się dać obraz rzeczywistości, próbuje definiować świat, gdy folklor - będąc obroną przed chaosem świata - tworzy symbole - hasła i znaki orientacji w świecie" (Sulima 1985, s. 19-21). Różnice dotyczą pojęć porządkujących świat - czasu, przestrzeni, bohatera. Literatura może włączać W swój zakres treściowy elementy folkloru ${ }^{9}$.

\section{BRATERSTWO PANCERNEJ DRUŻYNY}

Przyjaźnie zawierane przez załogi czołgów w Armii Czerwonej i Ludowym Wojsku Polskim były równie mocne jak ta spajająca w jedną, płynnie działającą całość „pancerną drużynę” z „Rudego”. Od sprawnego działania każdego i kolektywnego wypełniania powierzonych zadań bojowych zależał los własny i całej załogi. Każda zła decyzja dowódcy, pomyłka pozostałych, chwila nieuwagi, wahania, mogła być ostatnim, kosztownym błędem w życiu. Ciągłe napięcie, czas spędzony razem w śmiertelnym zagrożeniu pola walki, wspólne zabijanie wrogów czyniły z załóg czołgów, jeśli przeżyły wystarczająco długo, wspaniale zgrane zespoły: „Przyjaźnie wśród czołgistów były często bardzo mocne. Spędzali razem wiele godzin w ograniczonej przestrzeni, dzielili odpowiedzialność za maszynę i nierzadko dostosowywali czołg do siebie, wymalowując na nim hasła [...]. Załogi czołgów łączyła też groźba wspólnej śmierci. [...] Z 403272 czołgistów (łącznie z nielicznymi czołgistkami), których Armia Czerwona wyszkoliła podczas wojny, zginęło 310 000" (Merridale 2007, s. 235-236). Służba w czołgu była uważana przez żołnierzy za najbardziej niebezpieczną, zaraz po piechocie.

„Czołgowa śmierć" była jedną z najstraszniejszych, jakie przynosiła żołnierzom wojna - ci, którzy nie zostali rozerwani na kawałki przez eksplodującą amunicję, płonęli żywcem. Może właśnie z tego powodu czołgiści obu walczących stron nosili czarne kombinezony. Niemieccy pancerniacy dodatkowo mieli na wyłogach mundurów srebrne trupie czaszki, symbolizujące ich przynależność śmierci (dlatego Rosjanie często brali ich za esesmanów i wziętych do niewoli natychmiast rozstrzeliwali). Żołnierze służący w czołgach armii obu stron konfliktu mogli liczyć tylko na szczęście lub szybką śmierć: „Nawet najwięksi optymiści wiedzieli, co się wydarzy, gdy czołg zostanie trafiony. Rozgrzany do białości pocisk niemal na pewno zapali paliwo i amunicję czołgu.

\footnotetext{
${ }^{9}$ Wojenną postacią, funkcjonującą w obiegu literackim i ustnym, ukochaną przez radzieckich żołnierzy, a stworzoną przez częste odwołania do ludowej tradycji folklorystycznej, jest bohater niezliczonych opowieści Wasilij Tiorkin stworzony przez Aleksandra Twardowskiego.
} 
W najlepszym razie załoga - a w każdym razie ci, którym pocisk nie urywał głów lub członków - miała 90 sekund, by wydostać się na zewnątrz. Większość tego czasu pochłaniała szarpanina z ciężkimi, niekiedy rozgrzanymi do czerwoności włazami, które wybuch i tak mógł zaklinować. Pole bitwy to nie przystań, ale było bezpieczniejsze, niż opancerzona trumna, która właśnie zaczynała się palić, a jej metalowe elementy topić. To nie było po prostu «gotowanie»; czołg rozgrzewał też powietrze wokół siebie. Wtedy nie było już nadziei dla ludzi w środku. Zazwyczaj ich ciała były już tak spalone, że szczątków nie dawało się oddzielić" (Merridale 2007, s. 236). Złączonych za życia więzami przyjaźni, śmierć zmieniała $\mathrm{w}$ jedną garść popiołów. Środowisko walki i pancerny pojazd okazywały się skrajnie nieprzyjazne i śmiertelnie groźne. Jednak ciągła troska o czołg i niezawodne funkcjonowanie jego mechanizmów dawała załodze większą szansę na przeżycie bitwy. Zdjęcia czołgów z okresu drugiej wojny światowej pozwalają dostrzec namalowane na ich pancerzach kobiece imiona, rysunki niedźwiedzi, tygrysów, podków i wiele innych wzorów. Wydaje się, że załogi chciały w ten sposób „oswoić” swój pojazd, nadać mu indywidualny, wyróżniający rys, a także zażegnać potencjalne niebezpieczeństwa.

W podobny sposób postępują „pancerni”. Choć zagrażają im podstępni wrogowie i przeróżne pułapki, śmierć ich nie dosięgnie, ponieważ prócz niezwykłych umiejętności mają jeszcze jednego towarzysza — „Rudego”. „Bohaterowie Czterech pancernych przesiadają się z wiernego konia-druha do czołgu. Teraz czołg zastępuje bohaterskiego konia, który żył myślami bohatera, służył radą, przewidywał groźne i przychylne bohaterowi sytuacje" (Sulima 1985, s. 316). Motyw konia-przyjaciela dostrzegamy przy okazji poszukiwań odpowiedniej nazwy dla czołgu: „Dobry koń - powtórzył Janek. - Właściwie trzeba by nasz czołg jakoś nazwać. — Może Gniady — doradził Jeleń. — U mojego starzyka był gniady, nie bardzo wielki, ale dobry, wytrzymały... [...] - Aleksander Macedoński miał słynnego Bucefała - powiedział z uśmiechem Wasyl - a Roland podczas bitwy w dolinie Roncevaux dosiadał Wejlantyfa, rączego rumaka..." (Przymanowski 1977, s. 102). Nazwanie czołgu „Rudy” ma na celu odwrócenie uwagi sił nadprzyrodzonych zarówno od pojazdu, jak i od Marusi, noszącej przezwisko „Ogoniok”. Wszak w języku rosyjskim to słowo oznacza „ogieniek”, przed którym ma chronić „pancernych” gruba skóra ich konia: „W bajce bohaterskiej i tradycyjnym eposie ludowym nadawanie imienia było zagadnieniem szczególnej wagi i wiązało się z praktykami totemicznymi. Nadawanie imienia było jednocześnie zaklęciem i życzeniem. [...] Magiczno-życzeniowy charakter nazwy ujawnia się szczególnie silnie w związku z wykonaniem napisu na pancerzu" (Sulima 1985, s. 317). Czołg otrzymuje imię w związku ze szczególnymi wydarzeniami - pancerni uszli z życiem z wyjątkowo niebezpiecznej misji, a Marusię, postrzeloną przez niemieckiego snajpera, uratowali Janek z psem. Imię „Rudy” zostaje nadane na cześć rannej dziewczyny — sanitariuszki, która zaimponowała pancernym odwagą, a także jako magiczna ochrona przed ogniem - najgorszym wrogiem wszystkich czołgistów. 
Nadanie imienia możemy interpretować w jeszcze innym wymiarze. W światopoglądzie tradycyjnym słowo i oznaczany przedmiot są ze sobą ściśle związane, stanowią całość: „Nazwa jest podstawą definicji przedmiotu. Oznacza to, iż sam akt nazwania jest jednoznaczny z gestem kreatorskim. Za jego pomocą z niezróżnicowanego chaosu wydobywa się konkretną rzecz i przeciwstawia pozostałym przedmiotom, z którymi nie może być utożsamiony" (Kowalski 1989, hasło „Nazwa”, s. 340-341). W języku mitologicznym stworzenie czegoś jest jednoznaczne $z$ nadaniem nazwy, imienia. „Wypowiedzenie słowa, zwłaszcza gdy dzieje się to w szczególnych okolicznościach, np. zwiększonej mediacyjności, a więc kiedy otwarty jest kontakt z sacrum, jest jednoznaczne z przywołaniem (stworzeniem lub sprowadzeniem) nazwanego przedmiotu" (Kowalski 1989, s. 341). Stąd imię czołgu, które proponuje Olgierd: „czołg to znacznie więcej niż koń, coś znacznie bliższego. Po prostu, jak człowiek, jak towarzysz... Nazwijmy go «Rudy». [...] Przyjrzyj się: cały od ognia przyrudział, nabrał kasztanowej barwy. Marusia nie może się nazywać, bo to nie dziewczyna. Przed ogońkom niech nas pancerz strzeże. A «Rudy» - w sam raz” (Przymanowski 1977, s. 138). Nadanie nazwy „Rudy” tym bardziej możemy zinterpretować zgodnie z paradygmatem światopoglądu tradycyjnego, że na polu walki drużynie pancernych wciąż zagraża śmierć bądź rany, a więc szczególne/mediacyjne okoliczności.

W ciekawym opracowaniu służącym szkoleniu załóg czołgowych $z$ lat pięćdziesiątych, w rozdziale zatytułowanym „Czołgiści kochają swój sprzęt” czytamy: „Czołg - w pojęciu czołgisty - to nie tylko opancerzony i uzbrojony pojazd mechaniczny, który jeśli został uszkodzony w walce, może być opuszczony, a jego załoga [...] będzie walczyła pieszo. Czołg jako całość stanowi dla czołgisty narzędzie walki, potężny środek zwyciężania, potężną broń. Umiłowanie i przywiązanie czołgistów do swoich wozów bojowych zespala ich w jedną nierozerwalną potężną całość; jest to również jednym ze źródeł ich siły bojowej" (Lipka 1954, s. 82).

Czołg T-34: dom, narzędzie walki i przyjaciel pancernych, przez wielu historyków wojskowości jest nazywany „czołgiem, który wygrał drugą wojnę światową" ${ }^{10}$. To wyjątkowe narzędzie zadawania śmierci stanowi swój własny pomnik, nie tylko w krajach dawnego ZSRR, a więc w swej ojczyźnie, ale i w Polsce. Zdobi miejsca zwycięstw polskiego oręża, muzea, place przed szkołami i jednostkami pancernymi, jest nawet ozdobą kilku prywatnych kolekcji. W powieści i filmie czołg pełni bardzo ważną rolę, prawie nigdy się nie psuje,

$10 \mathrm{Na}$ temat czołgu T-34 i innych zob.: II wojna światowa, P. Matusak, E. Pawłowski, T. Rawski (red.), Bellona, Warszawa 2005; II wojna światowa. Encyklopedia uzbrojenia, A. Zasieczny (red.), Muza, Warszawa 2000; St. Żerko, Ilustrowany leksykon II wojny światowej, Kurpisz, Poznań 2004; A. Zasieczny, Czotgi II wojny światowej, Alma-Press, Warszawa 2005; J. Magnuski, Wozy bojowe LWP 1943-1983, Wydawnictwo MON, Warszawa 1985; jak też wiele monografii Wydawnictwa Militaria, opracowanych przez rosyjskich autorów. 
szczęśliwie i wiernie służy załodze, nie zawodzi jej w najtrudniejszych momentach. Dzięki niemu pancerni pokonują liczniejszego wroga, jego pancerz osłania ich przed ogniem, pociskami i śmiercią. Choć w czasie bitwy na Pradze załoga zostaje ranna, a trafiony czołg się pali, to jednak bohaterowie nie gina, tylko trafiają do szpitala, gdzie wkrótce lekarze przywrócą im zdrowie. „Rudy”, prowadzony wprawną ręką Grzesia, z wzorową załogą, nie daje szans niemieckim czołgom. Jest bowiem skonstruowany i wyprodukowany w Związku Radzieckim, a z kraju, w którym panuje najdoskonalszy ustrój na świecie komunizm, mogą pochodzić tylko najdoskonalsze wytwory myśli technicznej. Również załoga jest motywowana sowiecką ideologią, Olgierd i Grigorij są oddanymi komunistami, chcącymi uwolnić ludzkość od faszystowskiego zła i przynieść zniewolonej Europie wolność. Janek i Gustlik, jako ich towarzysze pancerni, są związani przysięgą na sojuszniczą wierność z ZSRR, który dał im doskonałą broń do ręki.

Czołgów T-34 ZSRR wyprodukował w czasie drugiej wojny światowej olbrzymią liczbę, około 55 tysięcy, czyli więcej niż Niemcy wszystkich typów swoich czołgów. Gdy do tego dodamy inne typy wozów bojowych, w tym słynne ciężkie JS - nazwane tak na cześć Józefa Stalina, możemy wyobrazić sobie potęgę sowieckiego pancernego walca, zgniatającego wszystko na swej drodze. W rzeczywistości T-34, zwłaszcza wytwarzany w początkach Wielkiej Wojny Ojczyźnianej, dawał załogom małą szansę przeżycia, między innymi ze względu na: niską jakość pancerza, silnika, urządzeń celowniczych, zawodność układu przeniesienia napędu, ciasnotę wnętrza, brak radiostacji czy nikłą możliwość obserwacji terenu. Co więcej, sowieccy czołgiści ze względu na ciągle niezaspokojone potrzeby frontu byli fatalnie wyszkoleni, przed wyruszeniem do bitwy spędzali $w$ maszynach zaledwie kilkadziesiąt godzin - to jedna $z$ przyczyn ogromnych strat wśród załóg czołgów na polu walki. Ci, którzy przeżyli, stanowili jednak zgrane zespoły, spajało je doświadczenie wspólnego uczestnictwa $\mathrm{w}$ walce i stawianie czoła niebezpieczeństwu.

\section{KULTURA ROBOTNICZA A SOCREALISTYCZNE MOTYWY "CZTERECH PANCERNYCH"}

Czterej pancerni propagują pewien typ bohatera i wartości, charakterystyczny zarówno dla kultury robotniczej w rozumieniu Czarnowskiego, jak i jej socrealistycznej wizji. Wedle Stefana Czarnowskiego, do nadrzędnych wartości charakterystycznych dla zjawiska określanego przez niego mianem nowej kultury należą: sprawiedliwość, solidarność klasowa, praca (rozumiana jako twórcze przekształcanie rzeczywistości), braterstwo, godność ludzka, honor. Kulturę robotniczą cechuje przy tym wyjątkowa spójność i zgodność, jakiej ludzkość nie znała od czasów średniowiecza, a także poczucie misji dziejowej tej klasy społecznej. Oczywiście, rozważania Czarnowskiego dotyczą okresu międzywojennego, jednak po 1945 r. władza ludowa chętnie odwoływała się do treści 
kultury robotniczej, pomocnych w rytualizacji życia publicznego. Widać to wyraźnie zwłaszcza w okresie socrealizmu, kiedy komunistyczni „rzemieślnicy” kultury usiłowali przydać jej nowych znaczeń.

W Polsce powojennej, aż do upadku komunizmu, wszystkie ważniejsze wydarzenia społeczne, strajki i protesty, wiązały się z robotnikami, traktowanymi przez władzę jako ważne ogniwo jej legitymizacji. W tym sensie dziewiętnastowieczny mit klasy robotniczej walczącej o dobro powszechne istniał nadal. Do tego mitu odwoływała się zarówno „Solidarność", jak i władza PRL, choć z innych powodów i w odmienny sposób.

W Polsce Ludowej pojęciem kultury robotniczej obejmowano sfery nie mające ze sobą wiele wspólnego: „Pojęcie to z jednej strony oznaczało model kultury tworzony w duchu zgodnym $z$ tradycjami światowego ruchu proletariackiego, a zarazem zwarty i wewnętrznie spójny układ przesiąknięty radykalizmem, internacjonalizmem, materializmem itd., z drugiej zaś strony kulturę mas" (Łysiak 1998, s. 96). Kultura robotnicza miała być też określeniem, przydatnym do opisu wszelkich przejawów twórczej aktywności klasy robotniczej, nosiciela tradycji warunkującej styl życia i uznawanych za ważne wartości. System socjalizmu państwowego odwoływał się do fundamentalnej roli robotników, wysoko stawiając w hierarchii wartości wspólnotę i pracę dla państwa. Kultura robotnicza, czy też raczej to, co jej mianem partia określiła, „poddana została idealizacji i mistyfikacji, w czym znaczny udział przypadł środkom masowego przekazu i propagandowej socrealistycznej literaturze" (Łysiak 1998, s. 96). Po wojnie władza ludowa głosiła konieczność „przebudowy kultury”, jej upowszechnienia, propagowania zainteresowań kulturalnych wśród milionowych mas obywateli, likwidacji analfabetyzmu i stworzenia systemu bezpłatnej, powszechnej oświaty, kapitalizm zaś - jak sądzono - hamował działalność twórczą mas ludowych i robotniczych, upośledzał je nie tylko ekonomicznie, ale i kulturowo. Nowy system, odwołując się do sprawiedliwości społecznej, podnosił problem rewolucyjnej budowy nowej kultury. Należało zatem ustalić, jakie treści „powinny składać się na nową ogólnonarodową kulturę. Przede wszystkim wskazywano na kulturę ludu pracującego: konieczne jest tu włączenie do jednej kultury narodowej tego, co najcenniejsze w kulturze robotniczej" (Nobis 1997, s. 86). Dla kultury robotniczej charakterystyczna była silna potrzeba przynależności do zbiorowości proletariuszy, których celem jest przekształcanie materialnej rzeczywistości. Wizja świata, którą proponowano, była klarowna i jasna: „Materia, którą zbiorowa praca przetwarza - to świat. Praca twórcza i, w dziedzinie ludzkiej, twórczy czyn rewolucyjny — to źródło wszelkich wartości. Reszta - to «nadbudowy», pozory, przez panujących nad światem karłów ustawione dekoracje, efekty kuglarskie zwodzące naiwnych" (Nobis 1997, s. 245). Obok pracy dwiema nadrzędnymi wartościami były sprawiedliwość i braterstwo. Czarnowski podaje przykład bezrobotnych proletariuszy, z którymi dzielą się jedzeniem inni, mający pracę robotnicy. Za swą postawę nie oczekują nagrody, ani nawet podziękowania. Nikt nie zasta- 
nawia się nad moralnym znaczeniem czynu. Po prostu jest on dla nich czymś „naturalnym”, tak właśnie należy postępować.

Podobnie jest w przypadku „pancernych”. Zawsze dzielą się z potrzebującymi, nie odmawiają nikomu jedzenia ani pomocy, nawet jeśli będzie to niemieckie dziecko. Zawsze starają się postępować sprawiedliwie, a okradający żołnierzy kucharz zostaje przez Janka i Gustlika zdemaskowany i ukarany. Za wzorową postawę żołnierską i odwagę w boju „pancerni” nie oczekują nagród, nie upominają się o medale i awanse. Wiedzą, że ich przełożony - „ojciec” brygady - wie o wszystkich zasługach swoich podwładnych i stosownie nagrodzi zasłużonych. Rzeczywistość, w jakiej funkcjonują „pancerni”, jest wolna od wszelkich wątpliwości, czy metafizycznych dywagacji. Jest absolutnie materialna, stworzona przez człowieka, a świat rzeczy materialnych (technika wojenna) ma służyć sprawnemu prowadzeniu walki i jak najszybszemu wygraniu wojny. Czy wykonywaną czynnością będzie zakładanie zerwanej gąsienicy, zabijanie esesmanów, nocne podchodzenie wroga, naprawa uszkodzonego czołgu czy ponowne uruchomienie fabryki - działanie musi być wykonane najsumienniej i najlepiej jak to możliwe.

Innym ciekawym motywem jest szacunek dla powierzonej broni (narzędzia pracy) i wielka o nią dbałość, emocjonalny stosunek oraz antropomorfizacja narzędzia walki - czołgu. Czołg, który jest ich wojennym domem, „pancerni” traktują $z$ wielką troską. Kiedy wyrywają się z okrążenia, wykonawszy niebezpieczne zadanie uratowania sojuszniczego batalionu kapitana Baranowa, bardziej dbają o „Rudego” niż o siebie: „Po pierwszej nocy, przespanej w stosunkowo spokojnych warunkach, odzyskali siły i wzięli się do roboty, by jak najszybciej doprowadzić wóz do porządku. O siebie mniej dbali i skończyło się na tym, że wkrótce zrzucili bandaże nałożone im przez sanitariusza" (Przymanowski 1977, s. 131). Po śmierci Olgierda, który kosztem własnego życia ratuje „Rudego” przed spaleniem, załoga nie chce porzucić zniszczonego czołgu. Właśnie na nim pragnie osiągnąć morski brzeg, czując, że jest do tego zobowiązana przez ofiarę bohaterskiego dowódcy. Przyczyny takiego stosunku do wojennego narzędzia zostają dokładnie wyjaśnione, gdy czołg jest uszkodzony w walce i technik brygady pancernej musi przyciąć armatnią lufę „Rudego”. Załoga tłumaczy chorążemu, starszemu, poważnemu mężczyźnie o „spokojnych ruchach fabrycznego majstra”, dlaczego nie chce „okaleczać" swego towarzysza walki: „My na «Rudym» od samego początku. Nie rzuciliśmy go, choć pułkownik chciał dać nowy, $z$ działem osiemdziesiąt pięć. [...] - Każda zadra na pancerzu, to jakby mnie samego skaleczył - dodał Jeleń" (Przymanowski 1977, s. 367). Technik, którego pierwowzorem literackiej postaci był chorąży Frydrych z brygady im. Bohaterów Westerplatte, wypowiada znamienne słowa: „Wiem, co was boli, bo od szczeniaka w fabryce robię. Kiedy zaczynałem, musiałem skrzynkę podstawić, żeby do tokarki sięgnąć. Jeśli maszynę lubić, jeśli koło niej chodzić i nie dać krzywdy zrobić, to ona odpłaci” (Przymanowski 1977, s. 367). 
W wyzwolonym przez Ludowe Wojsko Polskie Lublinie „pancerni” spotkają robotników, którzy ukryli przed wycofującymi się Niemcami maszyny fabryczne, a teraz pomagają odbudowywać zniszczone zakłady pracy: „Byli w Lublinie ludzie, którzy stawali od razu do roboty, nie pytając o płacę, przynosili z domu narzędzia, uruchamiali silniki i obrabiarki. Tym trzeba było pomóc" (Przymanowski 1977, s. 70). Gdy tylko następuje przerwa w boju, także załoga „Rudego" staje do pracy — pomaga w odbudowie lubelskiej fabryki, czy sieje zboże na pomorskich polach. Praca w systemie realnego socjalizmu Polski powojennej „nie była działaniem samorzutnym, nie mogła wynikać z potrzeby zaspokojenia problemów bytowych, nie była wartością indywidualną. Pracy, jako wartości kolektywnej, przyświecał "plan»" (Eysiak 1998, s. 98). Dodajmy, że nowy porządek zrytualizował pracę, do której odnosił się mit budowy wykreowany przez socjalistycznych propagandzistów: „Wznoszenie czegokolwiek nie miało być dlań zjawiskiem normalnym, powszechnym. $\mathrm{Z}$ założenia miało być jeszcze jednym $z$ argumentów manipulacji utwierdzających społeczeństwo o słuszności podejmowanych przez władze decyzji, o słuszności samego systemu" (Łysiak 1998, s. 99). Każdy akt budowy stawał się aktem kreacji nowego, lepszego jutra, dowodem mocy twórczej socjalistycznego państwa i jego awangardy - klasy robotniczej (słynne hasło: „Polska wielkim placem budowy").

Wspólnota i braterstwo w powieści Janusza Przymanowskiego są niezmiernie ważne. „Słowiańskimi braćmi” w walce i odbudowie zniszczonego wojną świata są Polacy i Rosjanie, a przyjaźn między narodami wyzwolonymi przez Armię Radziecką i Ludowe Wojsko Polskie rozkwita dzięki ustrojowi najlepszemu z możliwych, socjalizmowi, i jego humanistycznym wartościom. Komunizm „upodabniał się do religii przez swój nacisk na tezę o tworzeniu przez ludzi wspólnoty i działania, [...] prowadząc w kierunku jej wzmocnienia" (Kula 2003, s. 52). Działaniem spajającym grupę, a zarazem społeczną funkcją religii, jest wspólna wiara i podporządkowanie się autorytetom. Cały światowy proletariat miał wyznawać tę samą komunistyczną doktrynę uciskanych mas.

Komunistami są „Hiszpan”, prowadzący pancerną szpicę wyzwalającą obóz koncentracyjny, dowódca czołgu „Rudy” - Olgierd, a mechanik Grigorij jest komsomolcem. Radzieccy towarzysze broni, jak sierżant Czernousow, kapitan Pawłow, również są „wyznawcami świeckiej religii”, przedstawicielami świadomego klasowo proletariatu lub inteligencji pracującej, ludu miast i wsi. Nawet jeśli niektórzy ze „starej gwardii” zginą w walce, sztandar postępu dalej poniosą następni - młodsi, tacy jak Janek Kos. Komuniści uosabiają najlepsze cechy, są cisi, nie szukają poklasku ani pochwał. Żar ich wiary rozpala innych. Spokojni i opanowani, pomagają młodszym żołnierzom poznać wojenne rzemiosło, nigdy się nie cofają, walczą aż do śmierci. Motywuje ich przekonanie o słuszności walki w imię dobra całej ludzkości i wiara w nieuchronne zwycięstwo. Oczywiście, na prowadzącej do niego drodze konieczne są ofiary, ale 
każdy jest gotów je ponieść. Zanim zginą, starają się wpoić młodemu pokoleniu następców wartości, które stanowią centrum ich „świeckiej religii”, a które tak dokładnie charakteryzuje Stefan Czarnowski. Sądzi on, że przekonanie o konieczności przebudowy świata, tak by stał się sprawiedliwy, braterski i głęboko ludzki, jest formą mesjanizmu klasy robotniczej. „Ten mit - czytamy - ma swoje uzasadnienie - nie tylko źródło - w poczuciu, że jedynie praca jest twórcza" (Czarnowski 1989, s. 255). Robotnik jest przekonany o swej misji dziejowej, „czuje się czynnym ogniwem w maszynowo-ludzkim procesie przekształcania materii i społeczności ludzkiej” (Czarnowski 1989, s. 256). Badacz kultury robotniczej dodaje, że robotnik to człowiek walki, zwrócony w stronę świetlanej przyszłości, która jednak nie będzie odpoczynkiem, lecz nieustannym procesem twórczego wysiłku.

Wiemy, że szczególne więzy łączą „Rudego” z jego załogą. Podobnie jest w kulturze robotniczej: „Materialne środki produkcji, przede wszystkim właśnie maszyny, są dla proletariusza czymś bliskim, czymś przyjacielskim. [...] Jest to coś więcej niż [...] «animizm» maszyny: wyczuwanie w niej posłusznego woli robotnika, inteligentnego stworzenia. Tym bardziej więcej niż przejawiająca się u autorów «Pamiętników bezrobotnych" tęsknota do maszyny, wiernej przyjaciółki. To kult środków produkcji: maszyny, ognia wielkiego pieca, materiału, który zrzuca z siebie bezkształtną skorupę rudy" (Czarnowski 1989, s. 253). Narzędzia walki o lepsze, sprawiedliwe jutro czynią z człowieka demiurga, stwórcę rzeczywistości, nowego, pięknego świata radości i lepszego życia. Antropomorfizowane narzędzie, jakim jest „Rudy”, ma służyć celom, które wyjawia Olgierd: „Polubiliśmy nasz wóz, daliśmy mu imię, ale przecież tylko dlatego, że chcemy przynieść na nim ludziom wolność, chcemy jak najszybciej skończyć wojnę. Potem będzie pokój, zgoda między narodami, rozbrojenie..." (Przymanowski 1977, s. 155). Olgierd chce po zakończeniu walki wrócić do pracy meteorologa, Grzegorz będzie traktorzystą, Gustlik kowalem, a Janek pójdzie do szkoły. Każdy z „pancernych” po wygranej wojnie będzie dalej pracował ku wspólnemu dobru ludzkości.

Praca była bardzo ważną częścią przedwojennej egzystencji postępowej części społeczeństwa polskiego - chłopów, robotników i inteligencji pracującej - nadawała głęboki, choć nie zawsze uświadamiany przez nich sens ich życiu. Świadomość tę pomoże obudzić nowy, budowany także dzięki wojennemu wysiłkowi, ustrój społeczny — socjalizm. W budowie socjalizmu, tak jak w pracy, przodują oczywiście ludzie radzieccy, traktujący wojnę równie poważnie jak przedwojenny twórczy wysiłek, przekształcający przyrodę, podporządkowujący człowiekowi otaczający go materialny świat. Wiadomo już, dlaczego Niemcy wojnę przegrywają, a wygrywają Rosjanie. Nie tylko dlatego, że ci pierwsi są źli, a ci ostatni stoją po stronie dobra. Wojna niczego nie tworzy, lecz jedynie niszczy, a ludzkiej naturze przynależna jest nieustanna, doskonaląca świat i ludzkiego ducha twórcza praca. Janka Kosa uczył takiego poważnego podejścia do wykonywanych obowiązków ojciec - nauczyciel i oficer rezerwy. 
Gustlika Jelenia i Tomka Czereśniaka ludowej filozofii życia nauczono w rodzinnych domach. Grigorij Saakaszwili, Olgierd Jarosz, sierżant Czernousow oraz Iwan Pawłow to przedstawiciele zahartowanego w bojach kolejnych planów pięcioletnich narodu radzieckiego. Dołączający do załogi pod koniec wojny radziecki saper reprezentuje nowe pokolenie ludzi sowieckich, wychowane całkowicie według wzorów komunizmu, a także sowiecką inteligencję techniczną.

To nic, że w szeregach towarzyszy zabrakło Olgierda Jarosza i Iwana Pawłowa, że ludzkość poniosła wielkie straty w walce z niemieckim faszyzmem. Są inni, młodzi, którzy dalej z dumą poniosą sztandar socjalizmu, dobra, wolności i wspólnego wysiłku ku pożytkowi społeczeństwa. Janek, Gustlik, Tomasz i Grześ przeżyją wojnę, by w czasach pokoju budować nowy, wspaniały świat. To przekazanie sztandaru ukazuje gest śmiertelnie rannego kapitana Pawłowa: „Kos przyklęknął nad kapitanem. - Iwan... Ranny próbował uśmiechu. Dźwignął rękę i wyjął z kieszeni na piersiach zapalnik. - Wyrzuć, Janek, żeby kogo nie pokaleczył. Sięgnął raz jeszcze, podał suwak logarytmiczny, ale nie miał już sił, by mówić" (Przymanowski 1977, s. 710). Pawłow zostaje zabity przez młodego Niemca $\mathrm{w}$ mundurze volkssturmu, który wystrzelił ostatnią kulę, ale niemieckie miasto, jak wiele innych, ocaleje przed eksplozją podłożonych ładunków wybuchowych. Nie będzie zemsty, a ofiara kapitana nie pójdzie na marne, zwycięży socjalistyczny humanizm.

Motywy walki, pracy i postępu dziejowego zbliżają zaproponowaną przez autora Czterech pancernych wizję świata do tej kreowanej przez socrealizm, a także do wartości kultury robotniczej. Jest to dualistyczne spojrzenie porządkujące rzeczywistość w sposób charakterystyczny zarówno dla komunizmu, bajki magicznej, jak i mityzowanej pamięci, gdyż „komunistyczna filozofia historii zbudowana została wokół walki dobra za złem; reprezentowała wizję manicheistyczną i ciągle operowała pojęciem świeckiego Szatana" (Kula 2003, s. 26).

Ta „teologiczna”, posługująca się skrajnym wartościowaniem, wizja dziejów przedstawiała walkę dobra/komunizmu ze złem/kapitalizmem jako nieuchronny proces prowadzący do zwycięstwa „postępowych sił ludzkości”. W komunistycznej wizji dziejów, podobnie jak w micie, „każde wydarzenie, każdy najmniejszy szczegół, nawet każde słowo [...] należy do ustalonego porządku świata (po stronie słusznej lub niesłusznej), a więc zajmuje dokładnie wyznaczone miejsce na scenie i tym samym ma wyrazisty sens, którego kwestionować nie można" (Kula 2003, s. 27).

Świat oglądany przez pryzmat utworów socrealistycznych był uporządkowany i biało-czarny. Nie było miejsca na kolory pośrednie, co pozwalało każdemu odbiorcy sztuki na łatwą, jednoznaczną interpretację: „Z jednej strony («białej») byliśmy "my», nasz świat orbis interior (zapoznany, oswojony, waloryzowany dodatnio), z drugiej («czarnej») «ich» (obcy, wrogowie - przede wszystkim ideologiczni) orbis exterior (nieznany, peryferyczny, wraży, jałowy) 
— jednoznacznie cechowany ujemnie" (Paluch 1997, s. 143). Zauważmy, że podział oparty na binarnej opozycji występuje w micie, nadając rzeczywistości czytelny, dwudzielny charakter.

Pisząc o bliskich kulturze robotniczej motywach Czterech pancernych, nie można pominąć problematyki związanej z socrealistyczną wizją rzeczywistości, zawartą w literaturze powojennej Polski. Powieść Janusza Przymanowskiego obfituje w elementy topiki, etyki i estetyki realizmu socjalistycznego (zob. m.in.: Porębski 1988, t. 3; Lachowiecki, Markiewicz, Paczkowski 1988; Jarosiński 2007; Wojnowska 1996).

W Polsce zasady realizmu socjalistycznego w sztuce przedstawiono podczas ogólnopolskiej narady aktywu partyjnego w sprawach kultury w $1950 \mathrm{r}$. Socrealizm został uznany za najlepiej odzwierciedlający idee socjalistycznego postępu. Aktyw napiętnował wpływy burżuazyjnego abstrakcjonizmu, egzystencjalizmu i formalizmu. Sztukę realizmu socjalistycznego powinna cechować przede wszystkim ideowość, rozumiana jako zaangażowanie dzieła w walkę o socjalizm. Łączyła się z tym zasada typowości, czyli przedstawiania u ogólnionego sensu rzeczywiście istniejącego, jednostkowego zjawiska. Zasada ta, mająca źródła w dziewiętnastowiecznym realizmie, „w socrealizmie uległa znaczącej transformacji. Z klarownego pojęcia, oznaczającego odzwierciedlenie socjologicznych cech różnych grup społecznych, przeistoczyła się w nakaz realizacji ideologicznych nakazów i postulatów wysuwanych pod adresem literatury i sztuki przez partię komunistyczną" (Tubielewicz-Mattson 2004, s. 379).

Sztuka realizmu socjalistycznego, a więc także literatura, miała być zrozumiała, optymistyczna, nawiązywać do socjalistycznego postępu, przedstawianego w narodowej formie (język). Zadaniem socrealizmu była mobilizacja społeczeństwa do świadomego i twórczego udziału w budowaniu nowego ustroju, przekształcania rzeczywistości. Twórcy literatury powinni rozumieć wskazania partii i sugestywnie je przekazywać, spełniać funkcje propagandowe i wychowawcze. Pośród założeń polityki kulturalnej opracowanych przez PPR jeszcze podczas okupacji, a później rozwijanych w PZPR, znajduje się wiele stwierdzeń o konieczności nakłonienia inteligencji do działania na rzecz przemian i uczynienia z niej sojusznika partii. Nobilitowano klasę robotniczą i chłopów przez wprowadzenie wartości kultury robotniczej i silnego pierwiastka ludowości do kultury socjalistycznej ${ }^{11}$. W oficjalnej „wykładni” kultury ludowej władze pomijały jendak zupełnie jeden $z$ jej najważniejszych elementów — religijność. Kosmiczny porządek oparty na sakralności ziemi i uświęconej tradycji miał się nijak do proletariackiej wizji wspólnoty, misji dziejowej i kształtu materialnej rzeczywistości.

11 Pierwiastek ludowy w powieści Przymanowskiego reprezentują zwłaszcza postaci Czereśniaków (ojciec i syn), Gustlika, Wichury. O ludowym pierwiastku w kulturze zob. Topp 1997. 
Dla twórcy realizmu socjalistycznego użytecznym pięknem, realizującym się $\mathrm{w}$ życiu, był po prostu komunizm ${ }^{12}$. Jego wizja stanowiła punkt odniesienia i cel twórczości. Oczywiście, słowo „komunizm” w powieści Janusza Przymanowskiego nie pada często. Walka, którą prowadzi Ludowe Wojsko Polskie, jest słuszna, idzie bowiem o Polskę socjalistyczną, sprawiedliwą, mocno opartą na sojuszu najwartościowszych klas społeczeństwa - chłopów, robotników i postępowej inteligencji. Oni to wspólnym wysiłkiem mają budować nową, lepszą Polskę, mieszczącą się w historycznych granicach i stanowiącą szczęśliwy, wspólny dom dla wszystkich obywateli. Tacy właśnie są bohaterowie Czterech pancernych - robotnicy, chłopi. Towarzyszy im inteligencja pracująca, walcząca o przyszły wspólny dom - Polskę socjalistyczną. Społeczny awans po wygranej wojnie staje się udziałem bohaterów powieści. Czereśniak, małorolny chłop, bierze aktywny udział w tworzeniu demokracji ludowej jako poseł PPR — „rządzi Polską” i wraz z synem modernizuje wieś (elektryfikacja i reforma rolna): „zwieńczeniem awansu jest praca w najwyższym organie legislacyjnym (parlamencie), instytucji niegdyś całkowicie niedostępnej dla reprezentantów "mas ludowych», w nowej rzeczywistości najdoskonalej zaś wyrażającej ideę ludowładztwa" (Tomasik 2004, s. 16).

„Pancerni” tworzą zgraną drużynę, rozumieją się bez słów, w działaniu sprawni niczym mistrzowie: bohaterowie pracy socjalistycznej, są równymi sobie braćmi. Podobnie - w zgranym kolektywie działa cała polska armia, która nauczyła się sprawnego, bo wspólnego działania od narodu radzieckiego. Widać to we fragmencie przejazdu „pancernych" i żołnierzy radzieckich przez spaloną po powstaniu Warszawę. Miasto umarło, nie ma w nim ani domów, ani ludzi, a podróżujący, zastanawiają się nad możliwością odbudowy, porównują stolicę do Stalingradu i Smoleńska. Jak dokonać rzeczy, zdawałoby się, niemożliwych?: „Jak odbudować? [...] - Jeśli razem do roboty stanąć, to ludzie wszystko mogą. Ot, rebiata tu jadą, tankisty. Ich nieźle poharatało, a przecież załatali, wyleczyli i teraz wracają na front. Pragę wzięli, a Berlin będą brać..." (Przymanowski 1977, s. 182).

Na współdziałaniu, podobnie jak na słusznej ideologicznie motywacji, polega przewaga sojuszników nad Niemcami.

Stosunki między żołnierzami polskimi i radzieckimi są oparte na internacjonalistycznej równości, na wzajemnej przyjaźni i szacunku. Propagowanie nowych, kolektywnych form moralności i stosunków społecznych, opartych nie na zgubnym indywidualizmie, ale na kolektywie, jest w Czterech pancernych dobrze widoczne, podobnie jak nowy stosunek do pracy/walki, będącej godną człowieka, uszlachetniającą działalnością. „Pancerni” wyobrażają społeczny postęp, a raczej walkę o niego. Zło (niemiecki faszyzm) jest w powieści ukazane w zderzeniu z niwelującym jego skutki dobrem (socjalizm radziecki i polski).

12 O pięknie-użyteczności w koncepcji estetyki socrealizmu zob. Wołowiec 2004. 
W ostatecznym rozrachunku okazuje się, że życie ma sens, że warto czynić dobro i walczyć o nie, nawet ponosząc wielkie ofiary. Choćby zło miało początkowo przewagę, dobro i tak zwycięży. Widać tu socrealistyczny dydaktyzm.

Literatura socrealizmu miała zachęcać do dobrych uczynków i prawości, propagować pozytywnego, typowego bohatera: świadomego, dążącego do samodoskonalenia, posiadającego cechy heroiczne, zdolnego do bezinteresownych uczynków, poświęcenia w imię słusznej sprawy. Tacy są członkowie pancernej drużyny, a zwłaszcza Janek Kos. To właśnie on najpełniej odzwierciedla ideę samodoskonalenia nowego człowieka - wojna i walka w słusznej sprawie wyzwalają w nim najlepsze cechy, budują jego osobowość. Po śmierci Olgierda zostaje dowódcą, w końcu zaś otrzymuje awans oficerski - staje się podporucznikiem Ludowego Wojska Polskiego. Janek jest jednak, co prawda, wyjątkowym, ale przedstawicielem żołnierskiej zbiorowości. Bez kolektywu, indywidualnie, nikt nie mógłby walczyć ani sprawnie działać. Nawet okradający żołnierzy z jedzenia kucharz, kapral, Łobodzki, którego demaskują Janek i Gustlik, pod wpływem zbiorowości postanawia się zmienić, naprawić bohaterską postawą wyrządzone zło. Zmienia się też niedoświadczony, młody oficer, który uznał Janka Kosa za szpiega i bezzasadnie go aresztował, a nawet chciał rozstrzelać Tomasza Czereśniaka. Bohaterski sierżant Armii Czerwonej, przyjaciel załogi „Rudego”, wyjaśnia chorążemu zasady socjalistycznego zaufania i wiary w człowieka. Po czym zachęcony przykładem odwagi sierżanta Czernousowa wyróżnia się on odważnym atakiem na bronione przez Niemców miasto, otrzymuje medal i godzi się z „pancernymi”.

Powieść Janusza Przymanowskiego nie tylko ideologicznie zbliża się do zasad realizmu socjalistycznego. Również w warstwie stylistycznej odwołuje się do ideologicznego rozwoju fabuły, opowiadanie przeważa nad opisem i monologiem wewnętrznym. W opisie wyzwalania miast i uciemiężonych ludów Europy, ukazującym heroizm i entuzjazm mas żołnierskich oraz radość i wdzięczność ludności cywilnej, dostrzegamy romantyzm rewolucyjny. Stan teraźniejszy to zaledwie przejściowy etap na drodze do zwycięstwa sił postępu: „Tempo i nieuchronność rewolucyjnych przeobrażeń uzasadnia [...] potrzebę ukazywania rzeczywistości z pozycji dnia jutrzejszego, domeną prawdy czyniąc przyszłość i nadchodzące wraz z nią zwycięstwo idei komunistycznej" (Jarmułowicz 2004, s. 294).

Wewnętrzna przemiana bohatera odzwierciedla historyzm, „wyrażający się $\mathrm{w}$ traktowaniu postaci jako wewnętrznie zmiennych, rozwijających się przez uczestnictwo w wielkich zdarzeniach, prowadzących do ostatecznego celu (socjalizm); społeczny optymizm, czyli przekonanie, że chociaż może przegrywać bohater, nie przegrywa idea, klasa, naród" (Owczarek 1993, s. 923). Topikę socrealistyczną, a zwłaszcza przemianę żołnierza w bohatera, dobrego, szlachetnego człowieka (wpływ walki i komunistycznej ideologii), ukazuje wiele książek autorów radzieckich i polskich wydanych w latach 1946-1975. Nieco inne spojrzenie na te sprawy, brutalniejsze i bliższe okrutnej wojennej rzeczy- 
wistości, pojawia się we wspomnieniach radzieckich weteranów wydanych po 1989 r. (zob. Gonczar 1952; Biessonow 2005).

\section{ROSJANIE I NIEMCY — SOCREALISTYCZNA WIZJA DOBRA I ZŁA $\mathrm{W}$ „CZTERECH PANCERNYCH”}

Spróbujmy wymienić cechy, które w Czterech pancernych są przypisane Rosjanom i Niemcom.

Ro sja ni e: odważni, sprawiedliwi, lakoniczni w słowach i ruchach, chętnie pracują, walczą o wolność wszystkich uciemiężonych ludzi, toczą wojnę sprawiedliwą, „wojenna wspólnota” jest ich rodziną, jednoczy ich komunistyczna ideologia, nie są zawodowymi wojskowymi (nauczyli się zabijać z konieczności), przestrzegają wojennych konwencji, traktują Polaków jak młodszych braci, giną bez żalu, bo wiedzą, że tak trzeba, dla „sprawy” - w imię wolności i dobra, mają dobre i czułe serca, są skromni, podzielą się wszystkim, co mają, mistrzowsko opanowali sprzęt wojskowy i taktykę, chętnie śpiewają, wylewnie okazują uczucia, są przekonani o bliskim zwycięstwie, silni i wytrwali, pokonają wszelkie trudności, są dziećmi matki - natury, znawcami przyrody, potrafią działać nieszablonowo.

Niemcy: zawodowi wojskowi, wykonają bez wahania każdy zbrodniczy rozkaz, lubią poniżać i dręczyć słabszych od siebie, ludobójcy opętani zbrodniczą ideologią, twórcy obozów koncentracyjnych, okrutni i bezlitośni, chciwi, podstępni, niewolnicy autorytetów i drakońskiej dyscypliny, lubią zabijanie i wojnę, przypominają ludzi, ale działają jak posłuszne automaty, lubują się w odznaczeniach i mundurach, nie potrafią żyć bez hierarchii, bez rozkazu nic nie potrafią wymyślić, lubią porządek — są przy tym schematyczni i bezmyślni, łatwo ich zaskoczyć i zmylić.

Rosjanie i Polacy są przedstawieni w powieści Janusza Przymanowskiego jak socrealistyczni bohaterowie literatury okresu stalinizmu, mają rysy charakteru człowieka radzieckiego, wymieniane w Psychologii Borisa Tiepłowa czy pedagogicznych rozważaniach Antona Makarenki ${ }^{13}$. Możemy również stwierdzić, że cechy Rosjan sytuują ich po stronie dobra, Niemcy natomiast skazani są na przynależność do sfery zła ${ }^{14}$. Oczywiście wcielone dobro i zło muszą toczyć manichejski bój, w którym początkowo przewagę ma zło, jednak końcowe, ostateczne zwycięstwo należy do dobra. Warto odnieść ten problem do topiki literatury obiegów popularnych, to ona bowiem „operuje obrazami funkcjonującymi w kulturze od niepamiętnych czasów, powtarzającymi się schematami fabularnymi, stereotypami postaci oraz «skamielinami myślowymi». Dzieje się tak dlatego, że nadal żyją w niej w postaci zdegradowanej różnego rodzaju mity

13 Charakterystykę ludzi radzieckich w socrealizmie przedstawia Piotr Zwierzchowski (2000, s. 77-78).

14 O obrazie Niemca w powojennej Polsce ciekawie pisze Wojciech Lenarczyk (2001). 
i że dziedziczy ona konwencje «oswojone» przez ludową baśń magiczną i literaturę wysokoartystyczną" (Matuszewska 1993, s. 1104). To literatura popularna zachowała w swym przekazie najwięcej z ludowej topiki i schematów konstrukcji bohatera oraz przedstawianego świata. Obowiązująca zasada kompozycyjna to polaryzacja przedstawionego świata, dokonana wedle czarno-białego schematu aksjologicznego. Uproszczenie obrazu rzeczywistości wywodzi się z mitów o podziale świata na dobro i zło. Zasada binarnej polaryzacji świata dotyczy również bohaterów i ich wrogów - podziału na swoich i obcych: „W równie jaskrawy sposób uporządkowany jest binarnie świat przedstawiony utworów przygodowo-wojennych, szpiegowskich i polityczno-społecznych, w których [...] istnieją jedynie "nasi», posiadający wszelkie możliwe cnoty zewnętrzne i wewnętrzne, oraz "wrogowie», czyli odrażający wyglądem, brakiem kultury i jakichkolwiek zalet moralnych obcy" (Matuszewska 1993, s. 1105). Stereotypizacja świata przedstawionego dotyczy również bohatera. W powieściach przygodowo-wojennych wydawanych po drugiej wojnie światowej, adresowanych do młodych odbiorców, główną pozytywną postacią jest Niezwyciężony Heros (Kapitan Kloss, Janek Kos).

\section{POTRZEBA MITU}

Wydaje się, że centralnym, najważniejszym motywem Czterech pancernych i psa pozostaje wspólne działanie $\mathrm{w}$ imię dobra oraz szerszej wspólnoty ideowej. Mniejsza o szczegóły dotyczące wątków baśniowych: „Chodzi o to, iż bajkowe motywy wyrażają ludowy ideał działania kolektywnego, w tym przypadku ideał doskonałości wspólnot rodowych, realizujących niemal w sposób pierwiastkowy elementarne przedsięwzięcia kolektywu" (Sulima 1985, s. 321). Zbieżności między ludową epiką bohaterską, bajką magiczną i książką Janusza Przymanowskiego, na które możemy się powołać, są aluzją do rozległej tradycji epickiej, wywołaną przez czas walki z niemieckim najeźdźcą — powiada Roch Sulima. „Olbrzymia popularność Czterech pancernych tłumaczy się między innymi zespoleniem losu «indywidualnego bohatera» utworu, Janka Kosa, z losem «bohatera kolektywnego», załogi czołgu, a zarazem tysięcy Polaków [...]" (Sulima 1985, s. 321). Dodajmy, że bohaterowie powieści i filmu na jej kanwie powstałego są syntezą typów ludowego bohaterstwa, wręcz archetypem, rodem z żołnierskich opowieści, gawęd i pamiętników.

Mit „czterech pancernych” będzie istniał dalej, ponieważ jedną z podstawowych funkcji mitów jest wyjaśnianie rzeczywistości, sankcjonowanie podejmowanych działań i nadawanie im sensu. Inną funkcją mitycznych opowieści jest przekazywanie wzorów odpowiedniego postępowania, zasad etycznych, norm i wartości ważnych dla wspólnoty, a uosabianych przez bohatera. Mity pomagają ludziom rozumieć swą przeszłość i projektować przyszłość. 
Barbara Szacka (2006, s. 169) pisze: „W świadomości Polaków pamięć drugiej wojny światowej zajmuje istotne miejsce, przy czym jest to głównie pamięć losów rodziny i znajomych w tych dramatycznych czasach. Jej treścią jest przede wszystkim to, o czym mówili i milczeli rodzice, dziadkowie i babcie [...]. Jest to pamięć silnie sprywatyzowana. [...] Zwraca przy tym uwagę, że najwięcej wypowiedzi o wojennych losach pochodzi z dyskusji w najmłodszych grupach (18-35 lat)". Widać więc, że pamięć o najstraszniejszym konflikcie zbrojnym w dziejach ludzkości jest dla młodych ludzi ważna, tak jak pamięć o roli, jaka przypadła $\mathrm{w}$ nim do odegrania ich rodzinom. $Z$ jakiegoś powodu mit „,czterech pancernych" okazał się równie istotny, stając się częścią dyskursu pamięci zbiorowej Polaków dotyczącej zarówno wojny, jak i czasów dzieciństwa spędzonego w Polsce Ludowej.

\section{BIBLIOGRAFIA}

Biessonow Jewgienij, 2005, Tankista. Z Armią Czerwona do Trzeciej Rzeszy, tłum. Sławomir Kędzierski, Bellona, Warszawa.

Burszta Wojciech J., 1996, Czytanie kultury. Pięć szkiców, Lodart, Łódź.

Czarnowski Stefan, 1989, Powstawanie nowej kultury, w: Małgorzata Legiędź-Gałuszka, Czarnowski, Wiedza Powszechna, Warszawa.

Gonczar O., 1952, Chorażowie, Wydawnictwo MON, Warszawa.

Iggers Georg G., 2002, Użycia i nadużycia historii: o odpowiedzialności historyka za przeszłość w: Ewa Domańska (red.), Pamięć, etyka i historia. Anglo-amerykańska teoria historiografii lat dziewięćdziesiątych, Wydawnictwo Poznańskie, Poznań.

Jarmułowicz Małgorzata, 2004, Rewolucyjny romantyzm, w: Stownik realizmu socjalistycznego, Zdzisław Łapiński, Wojciech Tomasik (red.), Universitas, Kraków.

Jarosiński Zbigniew, 2007, Literatura $z$ lat 1945-1975, Wydawnictwo Naukukowe PWN, Warszawa.

Kula Marcin, 2003, Religiopodobny komunizm, Nomos, Kraków.

Kowalski Piotr, 1989, Leksykon znaki świata. Omen, przesąd, znaczenie, Wydawnictwo Naukowe PWN, Warszawa.

Lachowiecki Leszek, Markiewicz Tomasz, Paczkowski Marek, 1988, Polski socrealizm. Antologia publicystyki społeczno-kulturalnej z lat 1948-1957, Almapress, Warszawa.

Leach Edmund, Greimas Algirdas J., 2001, Komunikacja międzykulturowa, w: Edmund Leach, Rytuat i narracja, tłum. różni, Państwowe Wydawnictwo Naukowe, Warszawa.

Leeuw G. van der, 1997, Fenomenologia religii, tłum. Jerzy Prokopiuk, KiW, Warszawa.

Lenarczyk Wojciech, 2001, Dobry i zły Niemiec w oczach publicystów „Tygodnika Powszechnego” i „Kuźnicy” (1945-1950), w: Polska 1944/45-1989. Życie codzienne w Polsce 1945-1955, Instytut Historii PAN, Warszawa.

Lipka Czesław, 1954, Ogień czołgu, Wydawnictwo MON, Warszawa.

Łagowski Bronisław, 2005, Umarło w rzeczywistości, odżyto w stowach, „Przegląd”, 15 maja.

Łazarz Marek, 2006, Czterej pancerni i pies. Przewodnik po serialu i okolicach, Torus Media, Wrocław.

Łysiak Wojciech, 1998, Wielka kontestacja. Folklor polityczny w PRL, PSO, Poznań. 
Matuszewska Anna, 1993, Topika literatury obiegów popularnych, w: Słownik literatury polskiej XX wieku: Alina Brodzka i in. (red.), Ossolineum, Wrocław.

Merridale Catherine, 2007, Wojna Iwana. Armia Czerwona 1939-1945, tłum. Katarzyna Bażyńska-Chojnicka, Piotr Chojnicki, Rebis, Poznań.

Nobis Adam, 1997, Między upowszechnianiem a oświecaniem, w: Stefan Bednarek (red.), Nim będzie zapomniana. Szkice o kulturze PRL-u, Wydawnictwo Uniwersytetu Wrocławskiego, Wrocław.

Orliński Wojciech, 2006, Dlaczego pancerni i pies mieli kłopoty z cenzurą?, „Gazeta Wyborcza”, 30 października.

Owczarek Bogdan, 1993, Realizm socjalistyczny, w: Stownik literatury polskiej XX wieku: Alina Brodzka i in. (red.), Ossolineum, Wrocław.

Paluch Andrzej, 1997, Nierealny świat realnego socjalizmu, w: Stefan Bednarek (red.), Nim będzie zapomniana. Szkice o kulturze PRL-u, Wydawnictwo Uniwersytetu Wrocławskiego, Wrocław.

Porębski Mirosław, 1988, Dzieje sztuki w zarysie. Wiek XIX i XX, t. 3, Arkady, Warszawa.

Propp Władimir, 1976, Morfologia bajki, tłum. Wiesława Wojdyga-Zagórska, Książka i Wiedza, Warszawa.

Propp Władimir, 2000, Nie tylko bajka, tłum. Danuta Ulicka, Wydawnictwo Naukowe PWN, Warszawa.

Propp Władimir, 2003, Historyczne korzenie bajki magicznej, tłum. J. Chmielewski, Wydawnictwo KR, Warszawa.

Przymanowski Janusz, 1967, Ze stu jeden frontowych nocy, KiW, Warszawa.

Przymanowski Janusz, 1977, Czterej pancerni i pies, Krajowa Agencja Wydawnicza, Warszawa (wyd. V).

Przymanowski Janusz, 1979, Studzianki, Wydawnictwo MON, Warszawa.

Sroga Alojzy, 1974, Początek drogi. Lenino, Wydawnictwo MON, Warszawa.

Szacka Barbara, 2006, Czas przeszty, pamięć, mit, Scholar, Warszawa.

Szczerba Jacek, 2006, Ani pancernych, ani psa, „Gazeta Wyborcza”, 21 grudnia.

Szewczyk Łukasz, 2006, TVP bez komunistycznej propagandy, „Gazeta Wyborcza”, 8 lipca.

Sulima Roch, 1985, Folklor i literatura. Szkice o kulturze i literaturze wspótczesnej, Ludowa Spółdzielnia Wydawnicza, Warszawa.

Tomasik Wojciech, 2004, Awansu społecznego temat, w: Stownik realizmu socjalistycznego, Zdzisław Łapiński, Wojciech Tomasik (red.), Universitas, Kraków.

Topp Izolda, 1997, Od przeżytku do zabytku. Szkic do obrazu kultury ludowej w PRL-u, w: Stefan Bednarek (red.), Nim będzie zapomniana. Szkice o kulturze PRL-u, Wydawnictwo Uniwersytetu Wrocławskiego, Wrocław.

Tubielewicz-Mattson Dorota, 2004, Typowość, w: Słownik realizmu socjalistycznego, Zdzisław Łapiński, Wojciech Tomasik (red.), Universitas, Kraków.

Ulicka Danuta, 2000, Wstęp, w: Władimir Propp, Nie tylko bajka, wyb. i tłum. Danuta Ulicka, Wydawnictwo Naukowe PWN, Warszawa.

Walenciak Robert, 2005, Wojna o wojnę, „Przegląd”, 15 maja.

Wojnowska Bożena (red.), 1996, Literatura $i$ władza, IBL PAN, Warszawa.

Wołowiec Grzegorz, 2004, Piękno - użyteczność, w: Słownik realizmu socjalistycznego, Zdzisław Łapiński, Wojciech Tomasik (red.), Universitas, Kraków.

Zwierzchowski Piotr, 2000, Zapomniani bohaterowie. O bohaterach filmowych polskiego socrealizmu, Trio, Warszawa. 


\section{"FOUR MEN IN A TANK" AS A SOCIALIST REALIST MAGIC FAIRY-TALE}

\section{Summary}

One of the basic functions of myths is to explain reality, sanction the actions taken and give them a desirable meaning. Another function of mythical stories is to transmit the models of proper behaviour, ethical principles, norms and values personified by the hero that are important to a given community. Myths help people to understand their past and project their future.

Such a myth has taken shape in the area of popular culture and consciousness of the Poles under the influence of the television serial and the book Four Men in a Tank, by Janusz Przymanowski. It has become an inseparable part of the discourse of collective memory about World War II and childhood spent in People's Poland. Its chief motif is joint work in the name of the common weal and a larger unity of ideas. The author shows many convergences between Janusz Przymanowski's book, folk heroic epic and a magic fairy-tale. They are all inscribed in a larger epic tradition of the fight against the German invader. The heroes of the novel and the film created on its basis are a synthesis of the types of folk heroism, an archetype present in many soldiers' memoirs, tales and stories.

\section{Key words/słowa kluczowe}

magic fairy-tale / bajka magiczna; workers' culture / kultura robotnicza; socialist realism / socrealizm; war / wojna; memory / pamięć; popular culture / kultura popularna; myth / mit 